\title{
Time constraints on magmatism, mineralisation and metamorphism at the Falun base metal sulphide deposit, Sweden, using U-Pb geochronology on zircon and monazite
}

\author{
Tobias C. Kampmann ${ }^{\text {a,* }}$, Michael B. Stephens ${ }^{\text {a,b }}$, Magnus Ripa ${ }^{\text {b }}$, Fredrik A. Hellström ${ }^{\text {b }}$, Jarosław Majka ${ }^{\text {c,d }}$ \\ ${ }^{a}$ Department of Civil, Environmental and Natural Resources Engineering, Division of Geosciences, Luleå University of Technology, SE-971 87 Luleå, Sweden \\ ${ }^{\mathrm{b}}$ Geological Survey of Sweden, Box 670, SE-751 28 Uppsala, Sweden

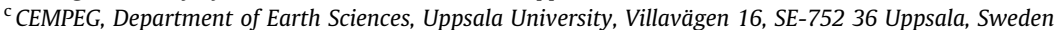 \\ ${ }^{\mathrm{d}}$ Faculty of Geology, Geophysics and Environmental Protection, AGH - University of Science and Technology, al. Mickiewicza 30, 30-059 Kraków, Poland
}

\section{A R T I C L E I N F O}

\section{Article history:}

Received 7 October 2015

Revised 9 March 2016

Accepted 19 March 2016

Available online 24 March 2016

\section{Keywords:}

Falun deposit

Fennoscandian Shield

SIMS U-Pb geochronology

Zircon

Monazite

Svecokarelian orogeny

\begin{abstract}
A B S T R A C T
$\mathrm{U}-\mathrm{Th}-\mathrm{Pb}$ (zircon and monazite) ion probe data have provided constraints on the timing of emplacement and metamorphism of magmatic rocks close to the Palaeoproterozoic, Falun base metal sulphide deposit in the Bergslagen lithotectonic unit, Fennoscandian Shield, Sweden, and, thereby the timing of mineralisation. Hydrothermal alteration and mineralisation at Falun are constrained to a short interval of several million years between a ${ }^{207} \mathrm{~Pb} /{ }^{206} \mathrm{~Pb}$ weighted average age of $1894 \pm 3 \mathrm{Ma}$ for a rhyolitic sub-volcanic rock in the felsic volcanic to sub-volcanic host rock suite, and a ${ }^{207} \mathrm{~Pb} /{ }^{206} \mathrm{~Pb}$ weighted average age of $1891 \pm 3 \mathrm{Ma}$ for a post-sulphide, porphyritic dacite dyke. Magmatism also included the emplacement of granite plutons with igneous crystallization ages of $1894 \pm 3,1894 \pm 2 \mathrm{Ma}$ and $1893 \pm 3 \mathrm{Ma}$. The felsic sub-volcanic to volcanic activity and the emplacement of dacite dykes and granite plutons overlap in age within their respective analytical uncertainties, indicating hydrothermal alteration and sulphide mineralisation inside a narrow time span of intense magmatic activity, and burial of the supracrustal rocks. Two distinct patchy and homogeneous metamorphic monazite types in a felsic volcanic rock around and hydrothermally altered rocks at the Falun deposit yield ${ }^{207} \mathrm{~Pb} /{ }^{206} \mathrm{~Pb}$ weighted average ages of $1831 \pm 8 \mathrm{Ma}$ and $1822 \pm 5 \mathrm{Ma}$, respectively. These ages fall well within the temporal range of a younger 1.84-1.81 Ga $\left(\mathrm{M}_{2}\right)$ metamorphic episode during the 2.0-1.8 Ga Svecokarelian orogeny, with the older episode $\left(\mathrm{M}_{1}\right)$ inside the Bergslagen lithotectonic unit at around $1.86 \mathrm{Ga}$. This shows the major influence of the $\mathrm{M}_{2}$ event in the north-western part of this unit, leading to a complete resetting of the $\mathrm{U}-\mathrm{Th}-\mathrm{Pb}$ isotope system in monazite.
\end{abstract}

(c) 2016 Elsevier B.V. All rights reserved.

\section{Introduction}

A major Palaeoproterozoic ore district in the Fennoscandian Shield occurs inside the Bergslagen lithotectonic unit in southcentral Sweden (Fig. 1; Stephens and Weihed, 2013). It comprises more than 6000 metallic mineral deposits, predominantly iron oxide and base metal sulphide deposits, commonly spatially and genetically related to a suite of felsic volcanic to sub-volcanic rocks (Stephens et al., 2009).

One of the largest base metal sulphide and precious metal deposits in the district, the metamorphosed Falun base metal sulphide deposit, is located in the north-western part of this lithotectonic unit (Fig. 1). A total tonnage of approximately 28-35 Mt of

\footnotetext{
* Corresponding author. Tel.: +46 (0) 920452891; fax: +46 (0) 920492818.

E-mail address: tobias.kampmann@ltu.se (T.C. Kampmann).
}

ore has been produced at average grades of $0.5-5 \% \mathrm{Zn}, 0.1-1.7 \%$ $\mathrm{Pb}, 0.7-4 \% \mathrm{Cu}, 13-35 \mathrm{~g} / \mathrm{t} \mathrm{Ag}$ and $0.5-4 \mathrm{~g} / \mathrm{t} \mathrm{Au}$ with variations between different ore types (Tegengren, 1924; Grip, 1978; Allen et al., 1996). It has been one of the economically most important base metal producers in Sweden and the world's largest producer of copper in the 17 th and early 18 th centuries. The mine closed in 1992.

So far, no radiometric age dating has been carried out with the specific aim to constrain the timing of the geological evolution, including hydrothermal alteration and mineralisation, around the Falun deposit. In this study, key rock units have been selected in order to constrain the timing of magmatism and metamorphism, using $\mathrm{U}-\mathrm{Pb}$ (zircon and monazite) geochronology. In addition, this study aims to test the genetic relationships between different suites of felsic sub-volcanic to volcanic and plutonic rocks at and around the deposit. The results of this study will form a basis for 


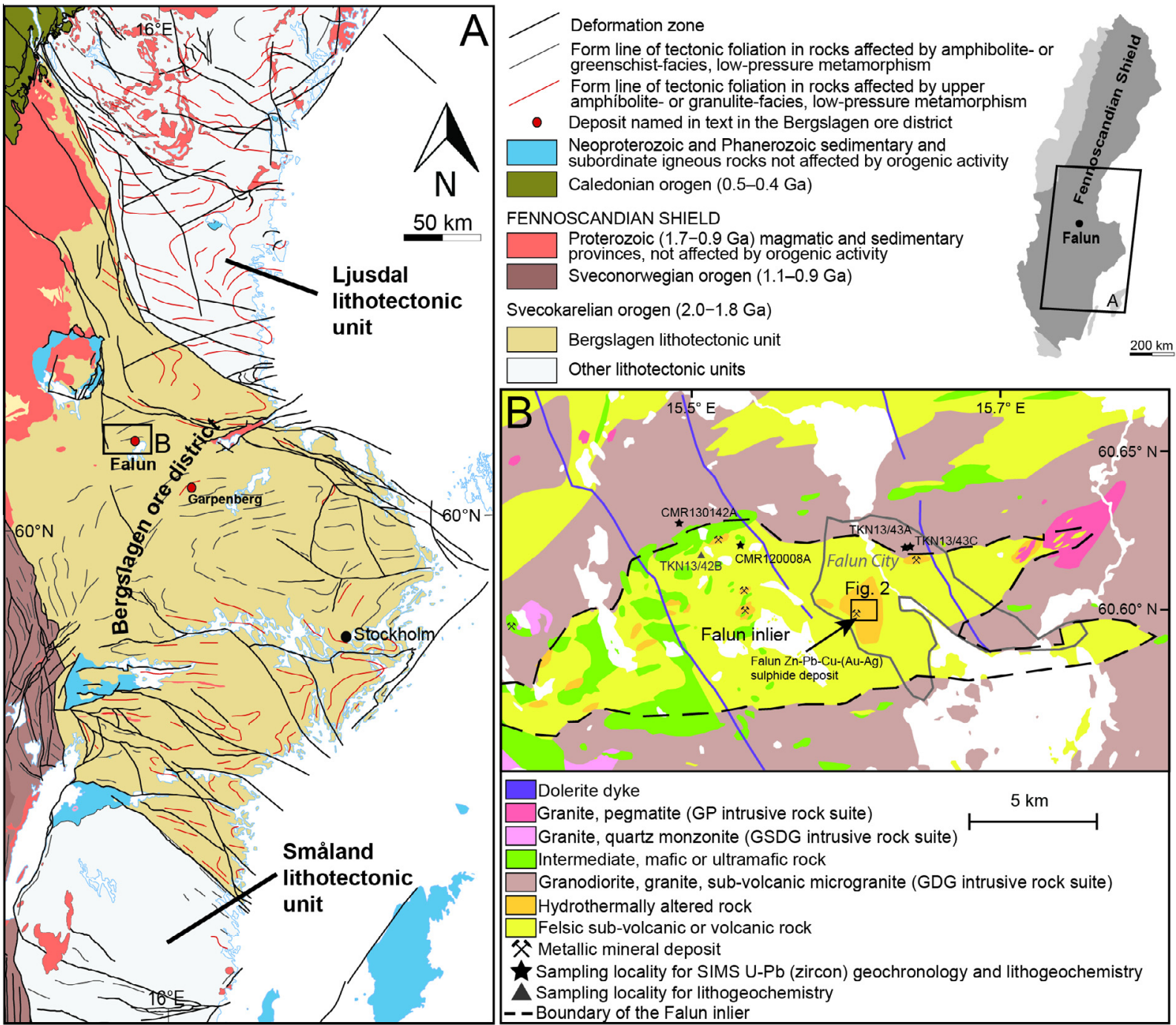

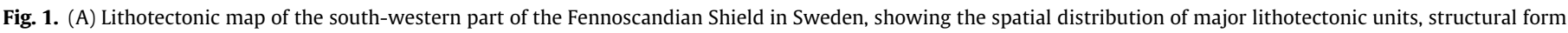

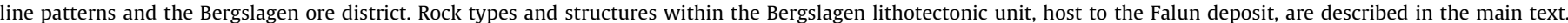

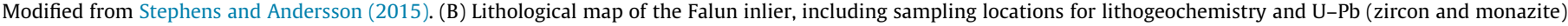
geochronology. Sampling locations in close vicinity to the Falun deposit are shown in Fig. 2. Modified after a map compilation by the Geological Survey of Sweden.

the understanding of the ore-forming processes at the Falun deposit and the geological evolution in this part of the Bergslagen lithotectonic unit.

A few data addressing the lithogeochemical character of the samples chosen for age determination work are included here. Since the Falun deposit has been considered to be a type example of base metal sulphide deposits in the Bergslagen ore district (Geijer, 1917; Magnusson, 1950, 1953; Allen et al., 1996), the results will have implications for the genesis of and exploration for base metal sulphide deposits in the district.

\section{Geological setting}

\subsection{Regional geological setting}

The 1.9-1.8 Ga Bergslagen lithotectonic unit forms a major component in the south-western part of the 2.0-1.8 Ga Svecokarelian orogen (Fig. 1) in the Fennoscandian Shield, Sweden. Orogenic activity in this lithotectonic unit was dominated by separate tectonic cycles, the more significant ones occurring during the time intervals $1.91-1.86 \mathrm{Ga}$ and $1.86-1.82 \mathrm{Ga}$ (Hermansson et al., 2008a; Stephens et al., 2009; Stephens and Andersson, 2015). The tectonic setting during each cycle involved a shift between retreating and advancing arc modes along a convergent active continental margin, transtension occurred in the retreating mode throughout the larger part of each cycle. Each transtensional stage was followed by shorter periods of transpression $\left(D_{1}\right.$ and $D_{2}$, respectively) in the advancing mode, around $1.87-1.86 \mathrm{Ga}$ and 1.84-1.82 Ga (Hermansson et al., 2007, 2008a; Stephens et al., 2009; Beunk and Kuipers, 2012; Stephens and Andersson, 2015). This orogenic development resulted in polyphase deformation and metamorphism under low-P, greenschist- to amphiboliteand locally granulite-facies conditions (Stephens et al., 2009).

One of the major lithological units in the Bergslagen lithotectonic unit is a folded belt of metamorphosed, predominantly felsic volcanic to sub-volcanic rocks, stratigraphically sandwiched between sequences of siliciclastic sedimentary rock mostly deposited as turbidite. The timing of igneous crystallization of the volcanic to sub-volcanic rocks is constrained between $\mathrm{U}-\mathrm{Pb}$ (zircon) ages of c. $1.91 \mathrm{Ga}$ and c. $1.89 \mathrm{Ga}$ for a metamorphosed rhyolitic mass flow and an amphibolite, respectively (Andersson et al., 2006; Stephens et al., 2009). The Falun deposit, as well as several other base and precious metal sulphide and many iron oxide 
deposits, which together form the Bergslagen ore district (Fig. 1A), are hosted by this volcanic belt, and are spatially closely associated with carbonate rock and skarn (Allen et al., 1996; Stephens et al., 2009). It has previously been shown that rocks in the hydrothermally altered zones at base metal sulphide deposits in this district (e.g. Trägårdh, 1991; Allen et al., 1996; Stephens et al., 2009), including Falun (Wolter and Seifert, 1984), were affected by later tectonic overprint during the Svecokarelian orogeny, which modified the alteration mineralogies. The term 'altered rocks' in this paper refers to rocks in the metamorphosed hydrothermally altered zone at the Falun deposit that have been affected by later metamorphism and ductile deformation; they are named according to their current metamorphic mineralogy.

The Bergslagen lithotectonic unit is dominated by large volumes and several generations of plutonic rocks which intruded into the mainly supracrustal sequence. The plutonic rocks have been divided into three distinct compositional suites, which can be distinguished further on the basis of age, metamorphic character and structural relationships (Stephens et al., 2009). The volumetrically most important suite is composed of granitoid rock, diorite and gabbro showing a calc-alkaline trend (GDG intrusive rock suite), which intruded at $1.90-1.87 \mathrm{Ga}$. Subsequent igneous activity at $1.87-1.84 \mathrm{Ga}$ and $1.81-1.78 \mathrm{Ga}$, including the so called Transscandinavian Igneous Belt (Högdahl et al., 2004), is dominated by granite, granodiorite, syenitoid rock, quartz monzodiorite and gabbro showing an alkali-calcic trend (GSDG intrusive rock suite). Mingling and mixing relationships between rocks with felsic composition and rocks with more primitive mafic composition are a prominent feature of the intrusive rocks in both the GDG and GSDG suites (Wikström and Andersson, 2004; Stephens et al., 2009). Granite, locally spatially associated with pegmatite and with high contents of uranium and/or thorium (GP intrusive rock suite), is also conspicuous in the Bergslagen lithotectonic unit and shows similar ranges in the timing of crystallization as the compositionally more heterogeneous, alkali-calcic rocks.

Both the supracrustal rocks and the GDG intrusive rock suite were emplaced prior to ductile transpressive deformation and metamorphism in the Bergslagen lithotectonic unit. The younger GSDG and GP suites crystallized after the onset of the ductile deformation but are affected, at least in part, by later ductile strain. Ductile deformation and low-grade metamorphism also locally affected the 1.81-1.78 Ga GSDG suite in the Småland lithotectonic unit (Fig. 1A) to the south.

\subsection{Falun inlier}

Falun is situated in the north-western part of the Bergslagen lithotectonic unit within a geological domain that trends ENEWSW referred to here as the Falun inlier (Fig. 1B). The inlier consists of felsic sub-volcanic to volcanic rocks and is surrounded by

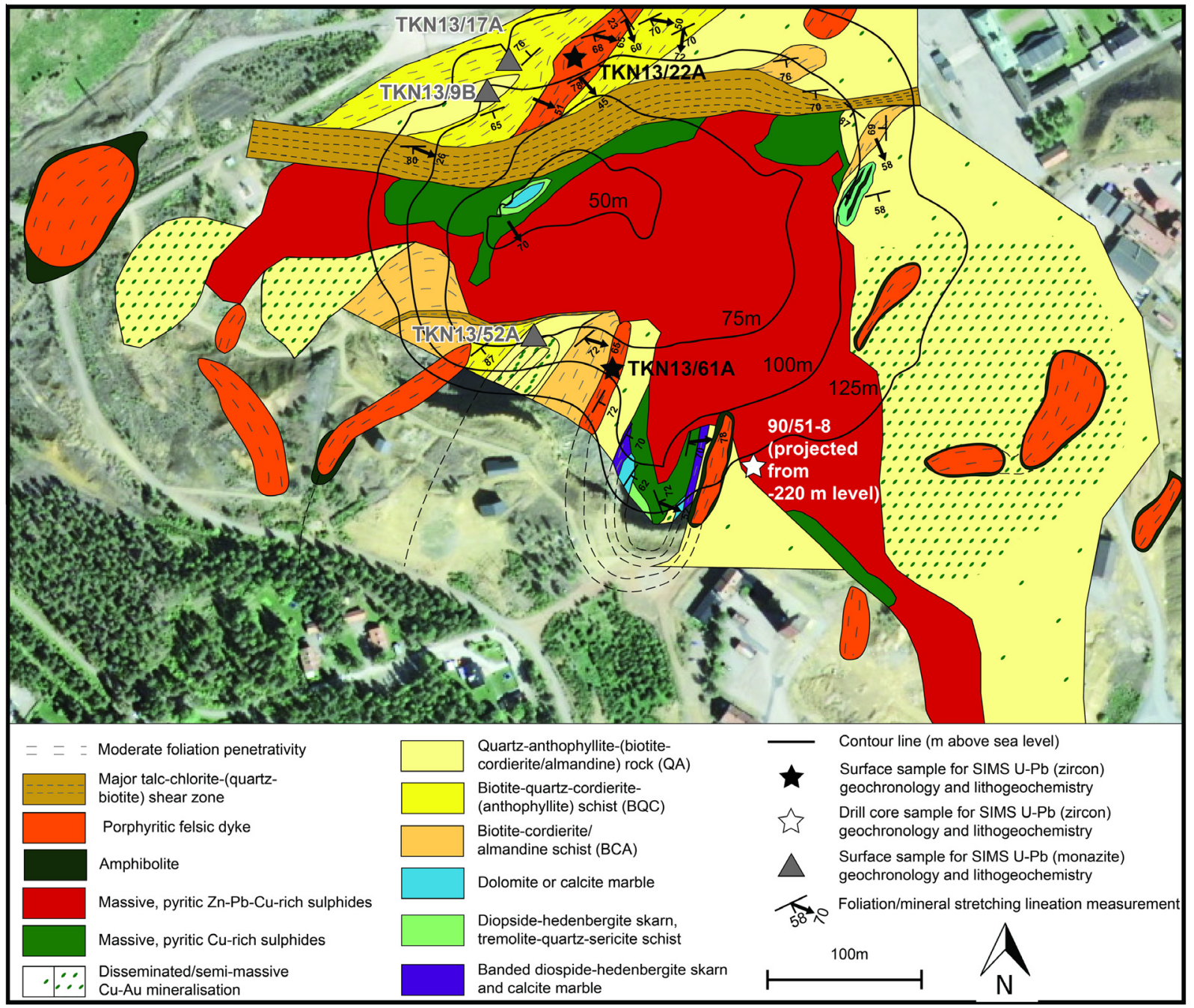

Fig. 2. Geological map of the Falun deposit, including sampling localities for porphyritic felsic dykes and metamorphosed, hydrothermally altered rocks. 
younger plutonic rocks with variable felsic to mafic and ultramafic composition (Fig. 1B). Extensive alkali alteration of the felsic rocks within the inlier was identified by Bromley-Challenor (1988). The felsic sub-volcanic to volcanic rocks are characterised structurally by polyphase ductile deformation. Major folds with axial surface traces trending E-W to NE-SW $\left(\mathrm{F}_{2}\right)$ and ductile shear zones with the same orientation deform an earlier foliation $\left(\mathrm{S}_{1}\right)$; the rocks are also affected by a steeply plunging mineral stretching lineation which probably represents a combination of $\mathrm{L}_{1}$ and $\mathrm{L}_{2}$ (Stephens et al., 2009). Metamorphism at peak metamorphic $\mathrm{P} / \mathrm{T}$ conditions of $2.5 \pm 1 \mathrm{kbar}$ and $550 \pm 50^{\circ} \mathrm{C}$, i.e. low-P, lower amphibolitefacies conditions, has been inferred, based on geothermobarometry on various mineral assemblages in the altered rocks (Wolter and Seifert, 1984).

Intrusive rocks delimiting the Falun inlier to the north and south comprise mainly deformed and metamorphosed, mediumgrained granite or granodiorite and subordinate microgranite, inferred to belong to the GDG intrusive rock suite (Fig. 1B). Mafic or ultramafic rocks, which are affected by a steeply plunging mineral lineation and large-scale folding, are also present both inside the inlier and in the surrounding bedrock, where they are in spatial association with the felsic GDG intrusive rocks. South-west of the inlier, some mafic intrusive rocks (Fig. 1B) show signs of magma mingling with 1.87-1.84 Ga GSDG granite to quartz monzonite. Stocks and dykes of granite and pegmatite, inferred to belong to the GP intrusive rock suite, also occur in the area (Fig. 1B). Dolerite dykes with NNW-SSE trend (Fig. 1B) dated to 0.95 Ga (Söderlund et al., 2005), represent the youngest magmatic component.

\subsection{Falun $\mathrm{Zn}-\mathrm{Pb}-\mathrm{Cu}-(\mathrm{Au}-\mathrm{Ag})$ sulphide deposit}

The Falun base metal sulphide and precious metal deposit is surrounded by a hydrothermally altered zone (Koark, 1962; Kampmann et al., 2016), which extends over an area of several thousand $\mathrm{m}^{2}$ (Fig. 1B). Hydrothermal alteration and subsequent polyphase ductile deformation and metamorphism resulted in different silicate-rich altered rock types, characterised by variable contents of quartz, biotite, cordierite, almandine garnet and anthophyllite (Kampmann et al., 2016; Fig. 2). Depending on their mica content, these rocks have an isotropic to weakly foliated or schistose character. Retrograde chlorite is common in the silicate-rich altered rocks and is also present along a major ductile shear zone, which bounds the massive sulphides to the north (Fig. 2). On a local scale in the mine, dolomite and calcite marble, as well as diopside-hedenbergite or actinolite-tremolite skarns occur (Geijer, 1917; Koark, 1962; Kampmann et al., 2016). Transitions between fine-grained felsic rock surrounding the deposit and silicate-rich altered rock have been observed in drill core close to the boundary of the hydrothermally altered zone at the Falun deposit, suggesting that the felsic rock formed the precursor to the silicate-rich altered rocks.

Mineralisation types at the Falun deposit include a major body of pyritic $\mathrm{Zn}-\mathrm{Pb}-\mathrm{Cu}$-rich massive sulphides in the central part, which is Cu-rich along its margins (Kampmann et al., 2016; Fig. 2). Other ore types are disseminated to semi-massive $\mathrm{Cu}-\mathrm{Au}$ mineralisation in quartz-anthophyllite-(biotite-cordierite-alman dine) rock, also hosting auriferous quartz veins on the eastern side of the deposit, and sulphide-bearing shear zones. Åberg and Fallick (1993) concluded that the auriferous quartz veins formed by fluidrock interaction involving meteoric water, after the emplacement of the massive sulphides and subsequent ductile deformation.

Porphyritic felsic dykes, macroscopically showing no or only weak signs of alteration compared to the silicate-rich altered rocks (Koark, 1962; Kampmann et al., 2016), intruded both the mineralised bodies and the surrounding hydrothermally altered zone at Falun (Fig. 2). The dykes are affected by the polyphase ductile deformation and metamorphism. These field relationships suggest emplacement during a late stage of or after the hydrothermal alteration event but prior to Svecokarelian ductile deformation and metamorphism. The dykes provide a key lithology for constraining the minimum age of hydrothermal alteration and mineralisation at the Falun deposit.

The Falun deposit is spatially associated with a large-scale fold structure which was described as a steeply SSE-plunging synform (Weijermars, 1987). Sheath folds have been identified in the massive sulphides, resulting in stretched and steeply plunging, rodshaped geometries, which extend down to approximately $450 \mathrm{~m}$ below sea-level (Kampmann et al., 2016). This also explains the thinning of massive sulphide bodies and associated convergence of rock units, including the porphyritic felsic dykes, towards the base of the deposit (Gavelin, 1989; Kampmann et al., 2016).

\section{Methodology}

\subsection{Sampling strategy and procedure}

A total of 10 rock samples were collected during field work. In addition, one sample of a porphyritic felsic dyke, situated in the sub-surface below the main massive sulphide body, was acquired from diamond drill core, now stored at the Geological Survey of Sweden's national drill core archive in Malå, Sweden. The samples were taken in order to:

1. Determine a maximum age for hydrothermal alteration and mineralisation by sampling the felsic sub-volcanic to volcanic host rock suite to the Falun deposit for $\mathrm{U}-\mathrm{Pb}$ (zircon) geochronology (one sample), assuming that this rock suite does not show the metamorphosed mineral associations characteristic of the hydrothermally altered rocks at the deposit (Fig. 1B).

2. Classify the alteration style in the hydrothermally altered zone at the deposit (Fig. 2; three samples) and compare it with the lithogeochemistry of the rocks sampled for $\mathrm{U}-\mathrm{Pb}$ (zircon) age determinations. Further work on the geochemical character of hydrothermally altered rocks at the Falun deposit is ongoing and will be complemented in a later study.

3. Determine a minimum age of hydrothermal alteration and mineralisation by analysing porphyritic felsic dykes (three samples) that intruded the Falun deposit and do not show the characteristic feldspar destruction visible in the altered rocks (Fig. 2).

4. Test the age relationships between the plutonic rocks surrounding the Falun inlier (three samples), inferred on the basis of composition and field relationships to belong to the GDG intrusive rock suite (Fig. 1B), the felsic sub-volcanic to volcanic rocks and the porphyritic felsic dykes.

5. Constrain the timing of metamorphism in the Falun area by $\mathrm{U}-\mathrm{Pb}$ (monazite) geochronology on altered rocks at the Falun deposit (Fig. 2; same three samples as in 2 above) and a felsic volcanic rock (mass flow) in the Falun inlier (Fig. 1B; one sample).

Sampled lithologies, the analytical methods used, key geometric and structural relationships, and the purpose of the analytical work are summarised in Table 1.

\subsection{Lithogeochemistry}

Lithogeochemical analysis was carried out on the samples selected for $\mathrm{U}-\mathrm{Pb}$ (zircon and monazite) geochronology. The samples were cleaned and $\sim 2 \mathrm{~cm}$ was cut off on each side in order to remove weathered parts. Further sample preparation was carried out by ALS Minerals in Piteå (Sweden) and subsequent analytical 


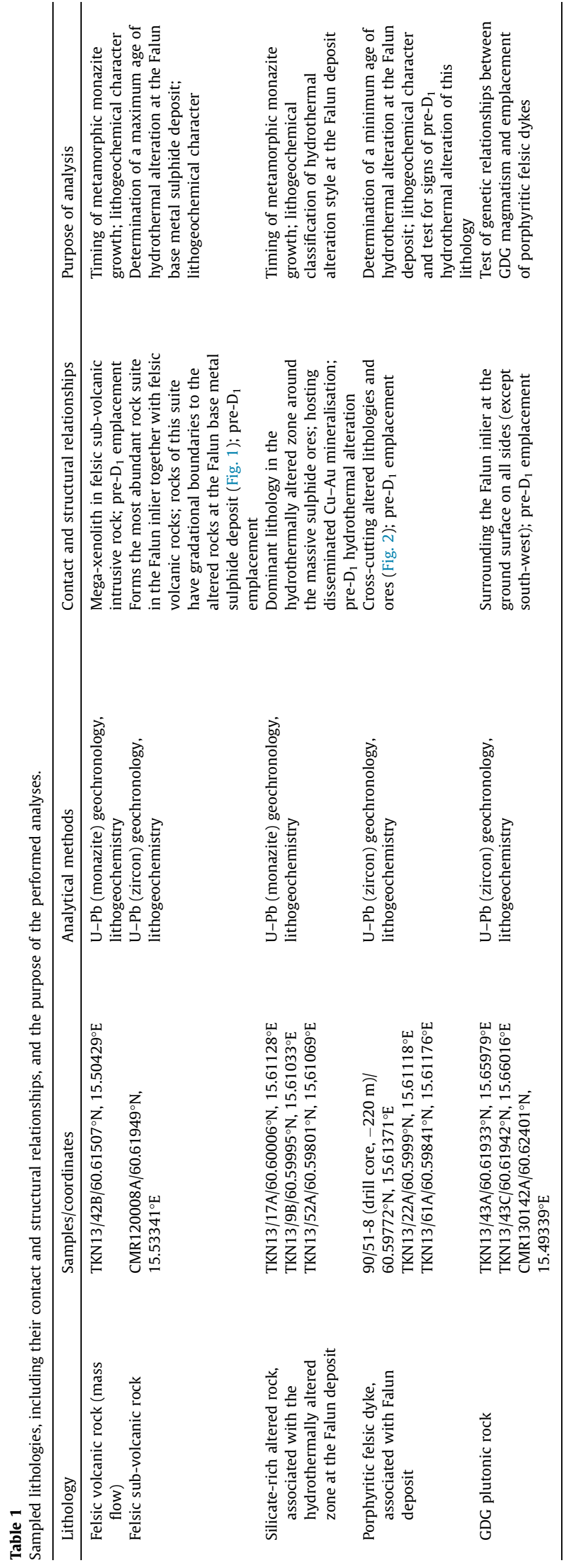

work performed at ALS Minerals in Vancouver (Canada) and Loughrea (Ireland).

Preparation involved crushing of the sample and pulverizing it to a powder using low-chrome steel grinding mills. Lithogeochemical analysis was conducted using Lithium Metaborate Fusion ICP-AES for major elements and ICP-MS for rare earth and trace elements. Additionally, aqua regia digestion ICP-MS was used to analyse for Se and Te. Due to a change of the whole-rock methodology used at ALS Minerals, the elements $\mathrm{Ag}, \mathrm{Cu}, \mathrm{Mo}, \mathrm{Ni}, \mathrm{Pb}$ and $\mathrm{Zn}$ were analysed by four-acid $\left(\mathrm{HNO}_{3}-\mathrm{HClO}_{4}-\mathrm{HF}-\mathrm{HCl}\right)$ digestion ICPAES for all samples except 90/51-8. The concentration of volatile components was determined by loss of ignition (LOI). An internal quality control at ALS Minerals returned results within the $2 \sigma$ error range for each of the analysed elements. Data were visualised in diagrams using the softwares GCD Toolkit (Janoušek et al., 2006) and ioGAS ${ }^{\mathrm{TM}}$.

\section{3. $\mathrm{U}-\mathrm{Pb}$ (zircon) geochronology and data presentation}

After crushing, washing and mineral density fractionation on a Wilfley table, $\sim 50$ to 70 zircon crystals and crystal fragments per sample were hand-picked under an optical microscope. Together with zircon chips of the Geostandards $1065.4 \pm 0.3 \mathrm{Ma}(1 \sigma)$ reference zircon 91,500 (Wiedenbeck et al., 1995), the selected zircons were mounted on a synthetic epoxy resin by staff at the NordSIM laboratory, which forms part of the Swedish Museum of Natural History, Stockholm, Sweden. The mount was polished to reveal internal textures and potential core-rim relationships in the zircon grains. All mounted zircon grains were examined prior to the $\mathrm{U}-\mathrm{Th}-\mathrm{Pb}$ isotopic analysis, using both conventional petrographic microscopy and scanning electron microscopy with backscattered electron (BSE) imaging (Zeiss Supra 35VP SEM, Uppsala University, Sweden) and cathodoluminescence (CL) imaging (Hitachi S-4300 FE-SEM, NordSIM laboratory). For each sample, 12 to 24 round spots, $20 \mu \mathrm{m}$ in size, were selected for $\mathrm{U}-\mathrm{Th}-\mathrm{Pb}$ isotopic analysis. The spots were selected so as to analyse homogeneous areas and avoid fractures in the crystals.

Prior to the U-Th-Pb isotopic analysis, the mount was coated with a $30 \mathrm{~nm}$ gold layer. The measurements of $\mathrm{U}-\mathrm{Th}-\mathrm{Pb}$ isotopic composition of the selected zircon spots were carried out using a Cameca IMS 1280 high-spatial and mass resolution secondary ion mass spectrometer at the NordSIM laboratory. For all analyses, an $\mathrm{O}_{2}^{-}$primary ion beam and an aperture were used to generate elliptical, flat-bottomed craters with a size of $\sim 15$ to $20 \mu \mathrm{m}$. The detailed analytical approach for zircon $\mathrm{U}-\mathrm{Th}-\mathrm{Pb}$ isotopic analyses at the NordSIM laboratory has been described earlier (Whitehouse et al., 1999; Whitehouse and Kamber, 2005). After five spot measurements, the analyses were interspersed with the reference zircon material. After the SIMS analysis, new BSE images were generated using a scanning electron microscope (Merlin Zeiss Gemini) at Luleå University of Technology, Sweden.

The analyses were corrected for initial common $\mathrm{Pb}$ according to the global Pb evolution model of Stacey and Kramers (1975). Based on the U-Pb analytical data, inverse concordia (Tera-Wasserburg) diagrams were plotted and ${ }^{207} \mathrm{~Pb} /{ }^{206} \mathrm{~Pb}$ weighted average ages were calculated using the Isoplot program (Ludwig, 2003). Where possible, concordia ages were also calculated. Radiometric dates and ages are reported with $2 \sigma$ errors, unless stated otherwise.

Due to the observation of a systematic reverse discordance in the U-Pb data for samples CMR120008A, CMR130142A, TKN13/43C, TKN13/61A and 90/51-8, discussed further below, a selection of points in all the samples except 90/51-8 was reanalysed using the same methodology, after repeated polishing and gold coating. This second round of polishing led to the erasing of the original analytical craters. 
Table 2

Lithogeochemical data of sampled rock units.

\begin{tabular}{|c|c|c|c|c|c|c|c|c|c|c|c|c|}
\hline \multirow{2}{*}{\multicolumn{2}{|c|}{$\begin{array}{l}\text { Sample } \\
\text { Rock type }\end{array}$}} & \multirow{2}{*}{$\begin{array}{l}\text { TKN13/42B } \\
\text { Felsic volcanic rock } \\
\text { (mass flow) }\end{array}$} & \multirow{2}{*}{$\begin{array}{l}\text { CMR120008A } \\
\text { Felsic sub-volcanic rock }\end{array}$} & TKN13/17A & TKN13/9B & TKN13/52A & $90 / 51-8$ & TKN13/22A & TKN13/61A & TKN13/43A & TKN13/43C & CMR130142A \\
\hline & & & & \multicolumn{3}{|c|}{$\begin{array}{l}\text { Silicate-rich altered rock, associated } \\
\text { with Falun base metal sulphide deposit }\end{array}$} & \multicolumn{3}{|c|}{ Porphyritic felsic dyke } & \multicolumn{3}{|c|}{ GDG plutonic rock } \\
\hline \multirow[t]{12}{*}{ Major elements (wt.\%) } & $\mathrm{SiO}_{2}$ & 79.9 & 78.3 & 63.7 & 68.6 & 73.6 & 74.7 & 76.6 & 74.6 & 74.8 & 76.4 & 70.8 \\
\hline & $\mathrm{Al}_{2} \mathrm{O}_{3}$ & 10.85 & 11.55 & 14.25 & 8.67 & 8.27 & 12.95 & 11.75 & 12.35 & 12.85 & 13 & 14.35 \\
\hline & $\mathrm{Fe}_{2} \mathrm{O}_{3 \text { _tot }}$ & 3.19 & 1.25 & 2.97 & 5.98 & 8.39 & 4 & 1.76 & 2.45 & 3.04 & 2.91 & 4.93 \\
\hline & $\mathrm{CaO}$ & 1.72 & 1.52 & 0.21 & 0.06 & 0.36 & 2.77 & 0.22 & 0.21 & 2.09 & 2.18 & 1.22 \\
\hline & $\mathrm{MgO}$ & 0.55 & 0.27 & 10.3 & 10.5 & 6.08 & 1 & 1.04 & 1.5 & 0.37 & 0.55 & 0.55 \\
\hline & $\mathrm{Na}_{2} \mathrm{O}$ & 3.46 & 5.57 & 0.09 & 0.04 & 0.08 & 3.36 & 1.12 & 0.71 & 4.02 & 4.56 & 4.61 \\
\hline & $\mathrm{K}_{2} \mathrm{O}$ & 1.24 & 0.37 & 2.07 & 0.54 & 0.05 & 0.93 & 6.69 & 5.17 & 2.6 & 0.81 & 3.15 \\
\hline & $\mathrm{TiO}_{2}$ & 0.15 & 0.13 & 0.22 & 0.14 & 0.11 & 0.31 & 0.19 & 0.23 & 0.21 & 0.21 & 0.32 \\
\hline & $\mathrm{MnO}$ & 0.05 & 0.04 & 0.04 & 0.17 & 0.04 & 0.08 & 0.03 & 0.13 & 0.08 & 0.06 & 0.09 \\
\hline & $\mathrm{P}_{2} \mathrm{O}_{5}$ & 0.02 & 0.02 & 0.01 & 0.02 & 0.01 & 0.07 & 0.03 & 0.05 & 0.05 & 0.04 & 0.08 \\
\hline & LOI (wt.\%) & 0.64 & 0.46 & 6.68 & 5.13 & 3.73 & 1.35 & 1.05 & 1.51 & 0.78 & 0.89 & 1.16 \\
\hline & Total oxides (wt.\%) & 101.87 & 99.5 & 100.56 & 99.86 & 100.73 & 101.64 & 100.74 & 101.54 & 101.02 & 101.66 & 101.42 \\
\hline \multirow[t]{37}{*}{ Trace elements (ppm) } & $\mathrm{v}$ & $<5$ & $<5$ & $<5$ & $<5$ & $<5$ & 22 & 16 & 17 & 9 & 9 & 17 \\
\hline & $\mathrm{Rb}$ & 26.1 & 6.3 & 55.4 & 13.2 & 2.2 & 24.9 & 83.6 & 54.5 & 226 & 77.2 & 61.1 \\
\hline & $\mathrm{Y}$ & 34.9 & 28.4 & 55.3 & 40.9 & 28.9 & 36.6 & 12.1 & 11.3 & 31.3 & 34.9 & 33.2 \\
\hline & $\mathrm{Zr}$ & 177 & 196 & 246 & 155 & 129 & 168 & 121 & 103 & 168 & 170 & 255 \\
\hline & $\mathrm{Nb}$ & 10.7 & 9.7 & 12.5 & 12.7 & 4.4 & 11.4 & 7.1 & 5.6 & 9.8 & 9.8 & 11.2 \\
\hline & Cs & 0.28 & 0.04 & 1.46 & 0.54 & 0.43 & 0.24 & 0.21 & 0.34 & 8.11 & 3.96 & 0.72 \\
\hline & $\mathrm{Ba}$ & 674 & 96.5 & 143.5 & 46.5 & 23.3 & 723 & 2230 & $>10,000$ & 1040 & 236 & 1270 \\
\hline & $\mathrm{Hf}$ & 4.7 & 4.8 & 6.8 & 4.3 & 3.6 & 4.6 & 3.1 & 2.6 & 4.7 & 4.7 & 6.3 \\
\hline & $\mathrm{Ta}$ & 0.7 & 0.7 & 1 & 0.5 & 0.5 & 1 & 0.6 & 0.4 & 1.2 & 0.7 & 0.8 \\
\hline & W & 1 & 0.14 & 1 & $<1$ & 1 & 3 & 2 & 5 & 1 & 1 & 0.33 \\
\hline & Th & 8.64 & 9.18 & 17.25 & 10.55 & 9.03 & 11.6 & 10.1 & 5.42 & 10.65 & 11.95 & 10.2 \\
\hline & $\mathrm{U}$ & 3.3 & 2.45 & 5.5 & 2.54 & 3.35 & 4.82 & 3.57 & 1.48 & 2.44 & 3.43 & 3.1 \\
\hline & $\mathrm{Ni}$ & $<1$ & 2 & $<1$ & $<1$ & 1 & $<5$ & 1 & $<1$ & $<1$ & 1 & 3 \\
\hline & Mo & $<1$ & 0.14 & $<1$ & $<1$ & $<1$ & $<2$ & $<1$ & 1 & $<1$ & $<1$ & 0.13 \\
\hline & $\mathrm{Cu}$ & 15 & 3 & 533 & 184 & 7140 & 21 & 11 & 24 & 12 & 6 & 39.1 \\
\hline & $\mathrm{Zn}$ & 20 & 28 & 87 & 1625 & 627 & 66 & 34 & 214 & 100 & 38 & 53 \\
\hline & $\mathrm{Ga}$ & 16.3 & 15 & 18.5 & 16.6 & 17.2 & 15.3 & 12.1 & 11.9 & 16.9 & 16 & 14.9 \\
\hline & $\mathrm{Se}$ & 0.4 & 0.4 & 0.7 & 1.1 & 30 & 1.2 & 0.3 & 0.2 & 0.7 & 1 & 0.5 \\
\hline & $\mathrm{Ag}$ & $<0.5$ & 0.02 & 1.2 & $<0.5$ & 4.2 & 2 & $<0.5$ & $<0.5$ & $<0.5$ & $<0.5$ & 0.01 \\
\hline & Sn & 2 & 3 & 6 & 3 & 10 & 2 & 2 & 7 & 19 & 6 & 3 \\
\hline & $\mathrm{Te}$ & $<0.01$ & 0.02 & $<0.01$ & $<0.01$ & $<0.01$ & 0.01 & $<0.01$ & $<0.01$ & $<0.01$ & 0.02 & 0.03 \\
\hline & $\mathrm{Tl}$ & $<0.5$ & $<0.5$ & 1 & $<0.5$ & 0.8 & 6.5 & 2 & 1 & 1.1 & 0.5 & 0.02 \\
\hline & $\mathrm{Pb}$ & 7 & 8 & 11 & 77 & 44 & 160 & 54 & 645 & 12 & 5 & 5 \\
\hline & La & 12.6 & 18.6 & 46.2 & 32.2 & 20.8 & 28.2 & 21.7 & 20.2 & 29 & 30.9 & 29.7 \\
\hline & $\mathrm{Ce}$ & 26.6 & 59.3 & 90.8 & 59.6 & 38 & 56.3 & 37.3 & 35.2 & 55.2 & 57.4 & 56.8 \\
\hline & $\operatorname{Pr}$ & 3.14 & 4.65 & 11.1 & 7.3 & 4.58 & 6.47 & 4.14 & 4.14 & 6.62 & 6.95 & 6.8 \\
\hline & $\mathrm{Nd}$ & 12 & 18.2 & 41.4 & 27.9 & 17.4 & 24.6 & 14.1 & 14 & 24.7 & 25.9 & 26 \\
\hline & $\mathrm{Sm}$ & 2.92 & 4.28 & 9.17 & 6.16 & 3.83 & 5.36 & 2.67 & 2.72 & 5.34 & 5.41 & 5.43 \\
\hline & $\mathrm{Eu}$ & 1 & 0.8 & 1.98 & 1.4 & 0.9 & 1.25 & 0.54 & 1.22 & 0.94 & 1.05 & 1.22 \\
\hline & $\mathrm{Gd}$ & 3.4 & 4.46 & 8.32 & 5.83 & 3.78 & 5.66 & 2.25 & 1.89 & 4.58 & 5.3 & 5.18 \\
\hline & $\mathrm{Tb}$ & 0.73 & 0.81 & 1.37 & 1 & 0.7 & 0.93 & 0.34 & 0.29 & 0.83 & 0.89 & 0.83 \\
\hline & Dy & 5.25 & 5.2 & 9.35 & 6.76 & 4.59 & 5.63 & 2.12 & 1.87 & 5.14 & 5.94 & 5.3 \\
\hline & Ho & 1.33 & 1.11 & 2.05 & 1.5 & 1.04 & 1.25 & 0.42 & 0.42 & 1.12 & 1.29 & 1.18 \\
\hline & $\mathrm{Er}$ & 4.01 & 3.2 & 5.99 & 4.31 & 2.98 & 3.69 & 1.27 & 1.27 & 3.25 & 3.74 & 3.59 \\
\hline & $\mathrm{Tm}$ & 0.65 & 0.51 & 0.95 & 0.68 & 0.48 & 0.57 & 0.2 & 0.21 & 0.51 & 0.56 & 0.52 \\
\hline & $\mathrm{Yb}$ & 4.78 & 4.15 & 6.31 & 4.23 & 3.14 & 3.95 & 1.48 & 1.44 & 3.42 & 3.91 & 3.84 \\
\hline & Lu & 0.78 & 0.7 & 1.04 & 0.71 & 0.54 & 0.62 & 0.23 & 0.26 & 0.57 & 0.65 & 0.61 \\
\hline
\end{tabular}


3.4. $U-P b$ (monazite) geochronology, U-Th-Y element mapping and data presentation

Monazite crystals were extracted, prepared and analysed following the same procedure as for zircon crystals, described above. The choice of analytical spots was based on BSE imaging performed at Uppsala University (Zeiss Supra 35VP SEM). For reference, the C83-32 monazite standard (Corfu, 1988) was used. Common Pb corrections, age calculations and data presentation were carried out in the same manner as for the U-Pb (zircon) geochronology. As for the zircon work, BSE images were generated one more time after the SIMS analysis, using the scanning electron microscope (Merlin Zeiss Gemini) at Luleå University of Technology. In addition, $\mathrm{X}$-ray relative element distribution maps for $\mathrm{U}$, Th and $\mathrm{Y}$ were created using an electron probe microanalyzer (Jeol JXA-8530F HyperProbe) at the Department of Earth Sciences, Uppsala University, with a beam current of $50 \mathrm{nA}$ and an acceleration voltage of $20 \mathrm{kV}$.

\section{Results}

\subsection{Lithogeochemical classification}

The lithogeochemical data are presented in Table 2 and shown in Fig. 3. The sampled lithologies show a variable style and degree of pre-metamorphic, hydrothermal alteration in an alteration box plot (Fig. 3A; Large et al., 2001). The alteration indexes used in this diagram, the Ishikawa alteration index (AI; Ishikawa et al., 1976) and the chlorite-carbonate-pyrite index (CCPI; Large et al., 2001), have been designed mainly for the classification of alteration in volcanic rocks spatially associated with volcanogenic massive sulphide (VMS) deposits. However, sampled sub-volcanic and plutonic rocks are included here in order to be able to compare alteration styles and intensities between all the sampled lithologies. The volcanic rock classification diagram with immobile element ratios after Winchester and Floyd (1977) and the plutonic rock classification diagram after Middlemost (1994) have been used to determine the composition of the samples.

The volcanic rock sample (TKN13/42B) from the Falun inlier, classified in the field as a felsic mass flow, lies close to the boundary between the least-altered dacite and rhyolite fields in the alteration box plot (Fig. 3A). The felsic sub-volcanic rock (CMR120008A) plots towards the albite end-member corner, indicating sodic alteration. Neither of these rocks has been affected by hydrothermal chlorite-sericite-pyrite alteration. They have a rhyolitic composition according to the volcanic rock classification diagram (Fig. 3B).

The three samples of silicate-rich altered rocks from the hydrothermally altered zone at the Falun deposit form a cluster in close proximity to the chlorite-pyrite end-member corner of the alteration box plot (Fig. 3A). This indicates intense chlorite-ser icite-pyrite alteration, characteristic of the proximal footwall alteration system to VMS deposits (Large et al., 2001).

One sample of porphyritic felsic dyke, situated below the central massive sulphide body (90/51-8; Fig. 3B), lies in the leastaltered dacite box in the alteration box plot (Fig. 3A). The two samples of the same lithology from the ground surface (TKN13/22A and TKN13/61A; Fig. 3A) show a trend towards the sericite alteration end-member. Compared to all other lithologies, these two samples show elevated concentrations in the relatively mobile components $\mathrm{K}_{2} \mathrm{O}(>5 \mathrm{wt} \%)$ and $\mathrm{Ba}(>2000 \mathrm{ppm})$, and lower concentrations of $\mathrm{CaO}(<0.3 \mathrm{wt} \%$; Table 2$)$. All the porphyritic felsic dyke samples show a dacitic composition in the volcanic rock
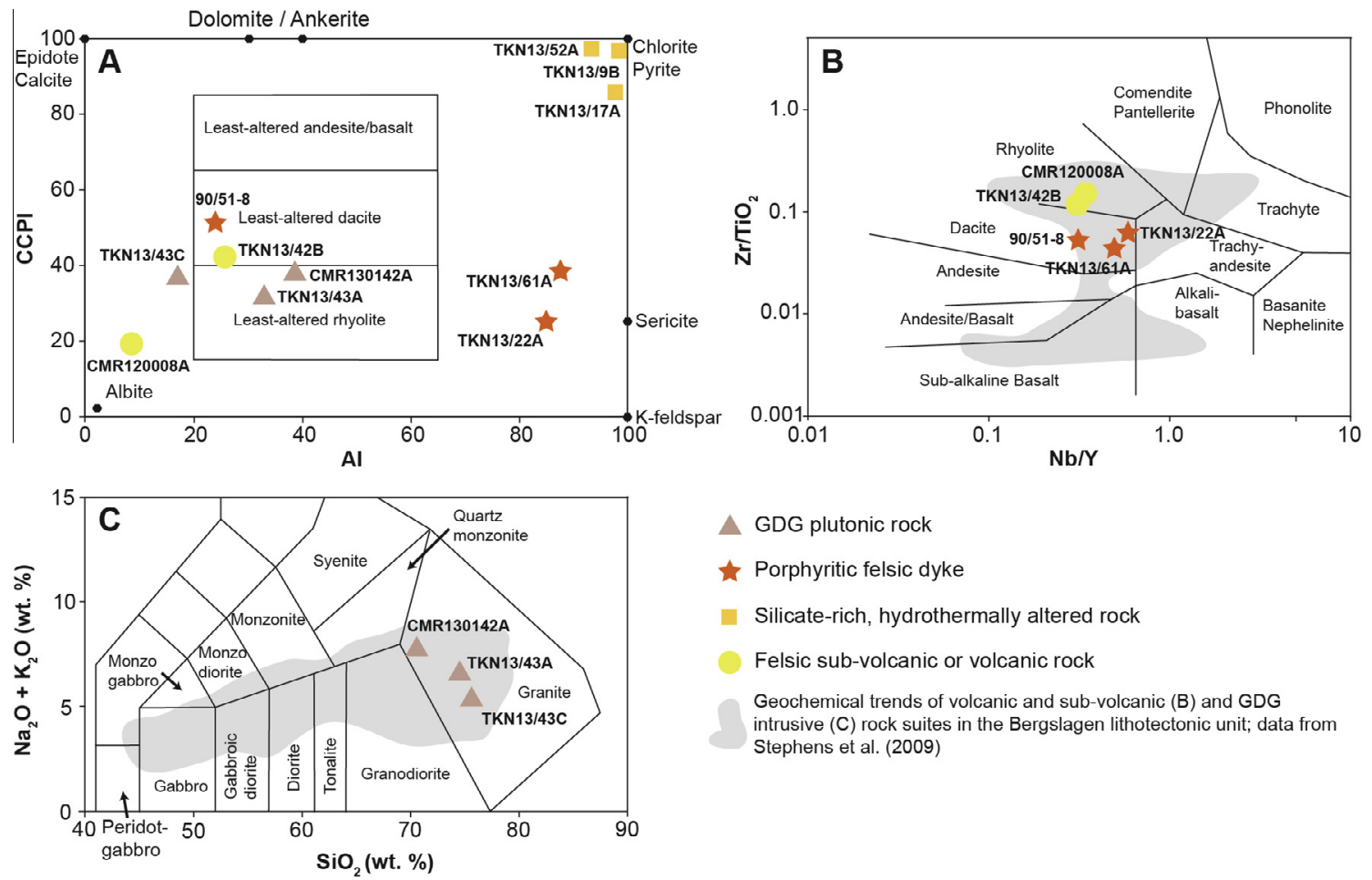

Stephens et al. (2009)

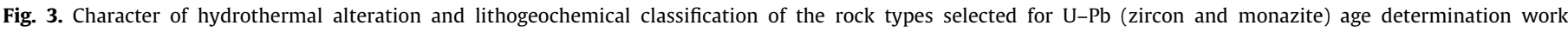

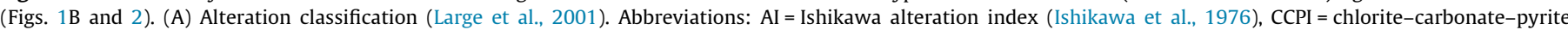

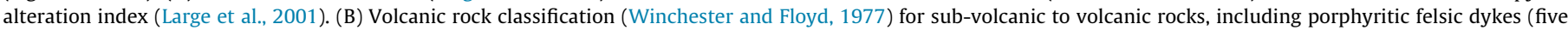

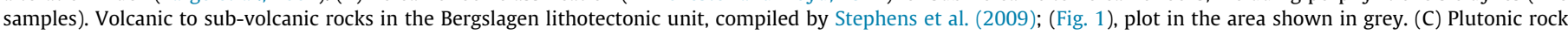

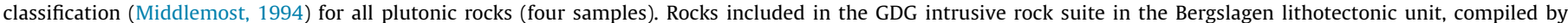
Stephens et al. (2009), plot in the area shown in grey. 


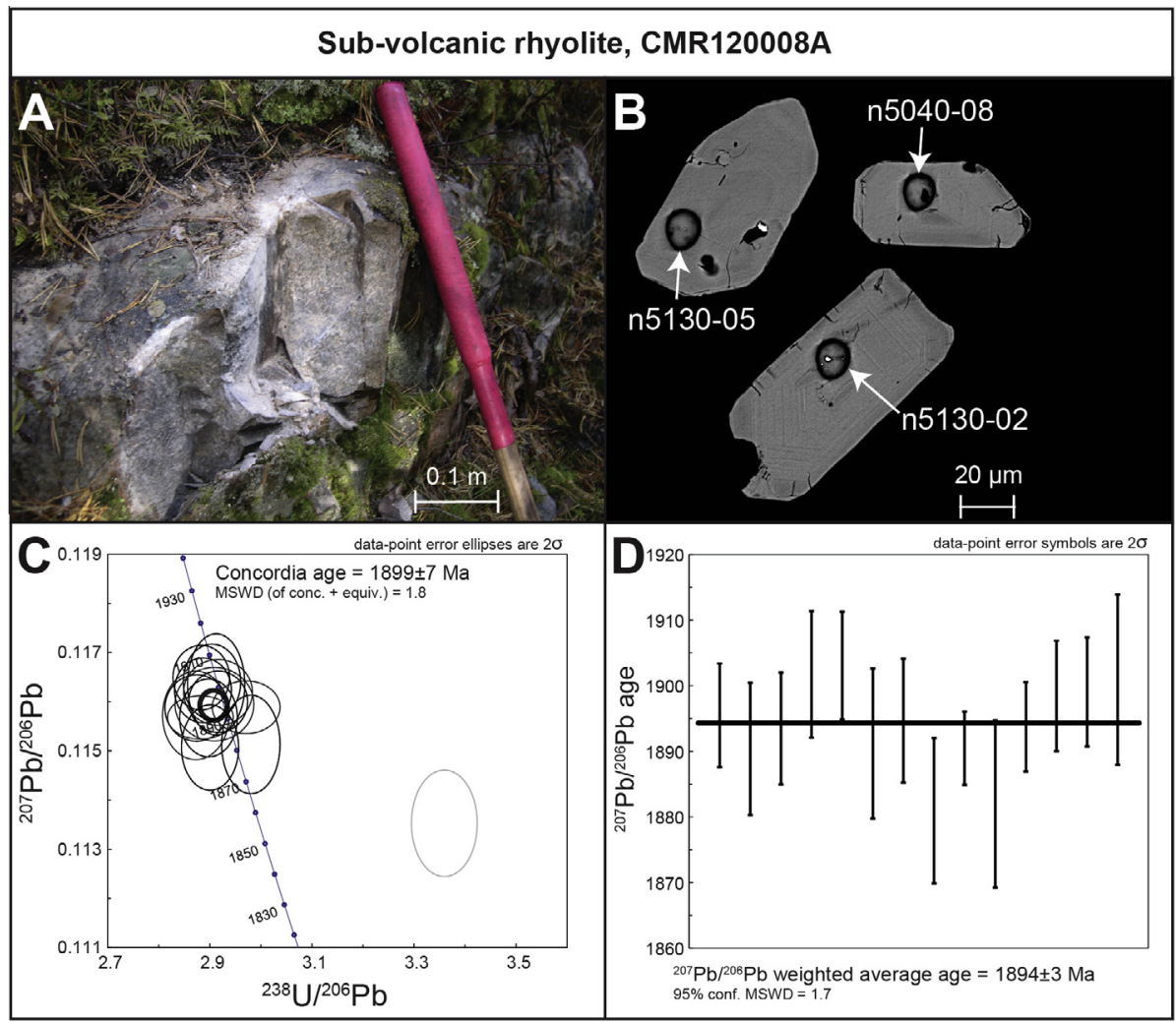

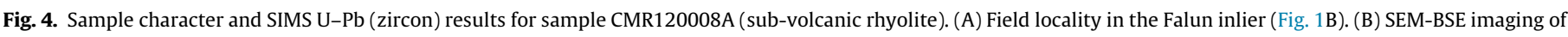

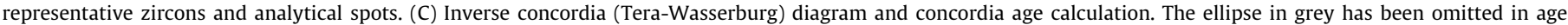
calculations. (D) ${ }^{207} \mathrm{~Pb} /{ }^{206} \mathrm{~Pb}$ weighted average age at the $95 \%$ confidence level, using the same analyses as in $\mathrm{C}$.

classification diagram (Fig. 3B), but with high $\mathrm{SiO}_{2}$ contents around 75\% (Table 2).

Samples of felsic plutonic rocks inferred to belong to the GDG intrusive rock suite (TKN13/43A, TKN13/43C and CMR130142A) plot as least-altered or only weakly altered rocks with a rhyolitic (granitic) composition in the alteration box plot diagram (Fig. 3A). In the plutonic rock classification diagram (Middlemost, 1994; Fig. 3C), the samples also show a granitic composition (Fig. 3C).

\section{2. $\mathrm{U}-\mathrm{Pb}$ (zircon) geochronology}

The following section presents site and sample descriptions, zircon morphology, U-Th- $\mathrm{Pb}$ (zircon) analytical results and the resulting interpretation of the igneous crystallization age of each sample, sorted by analysed lithology. The U-Th-Pb analytical results are shown in the Inline Supplementary Material (Table S1). Strongly reverse discordant data points in four samples (CMR120008A, CMR130142A, TKN13/43C and TKN13/61A), obtained in the initial round of analyses, have been replaced by less discordant data obtained during the reanalysis of these samples. All ages presented in the following text, including ${ }^{207} \mathrm{~Pb} /{ }^{206} \mathrm{~Pb}$ dates of individual analytical spots, are referred to with their respective $2 \sigma$ uncertainties. A few analyses with more than $1 \%$ discordance (within $2 \sigma$ error) were omitted in all the age calculations (Table S1) and are not discussed further here.

Inline Supplementary Table S1 can be found online at http:// dx.doi.org/10.1016/j.precamres.2016.03.011.

Exceptionally high concentrations in $U$ or analysis of metamict domains in zircon can be a cause of reverse discordance, owing to matrix-related ion yield effects (Williams and Hergt, 2000; White and Ireland, 2012; Kusiak et al., 2013). Neither elevated U concentrations nor significant metamict alteration in zircon domains have been observed. Reverse discordant behaviour is attributed more probably to roughness or unevenness of the epoxy surface, which might have been caused by the pre-analytical SEM imaging or uneven polishing of the epoxy mount. Uneven epoxy surfaces have been shown to affect the charging and beam extraction behaviour around the analytical areas and, subsequently, bias the results towards reverse discordant behaviour (M. Whitehouse, personal communication 2014).

In all cases, a second analysis of the more discordant analytical spots ( $2 \sigma$ lim. disc. $>1 \%$ ) led to a shift of the data ellipse towards concordia on a sub-horizontal line from the original data ellipse, i.e. without any significant changes in the ${ }^{207} \mathrm{~Pb} /{ }^{206} \mathrm{~Pb}$ ratios. As a consequence, it was possible to calculate concordia ages for all samples, although some reverse discordance remained. For this reason, the concordia ages of samples where the concordia ellipse does not overlap with the concordia line $(2 \sigma \mathrm{lim}$.) may be erroneously old. This concerns samples 90/51-8, TKN13/61A, TKN13/43C and CMR130142A. In these cases, the ${ }^{207} \mathrm{~Pb} /{ }^{206} \mathrm{~Pb}$ weighted average age should not be affected by horizontally reverse discordance (e.g. Kusiak et al., 2013). Consequently and for reasons of consistency, the ${ }^{207} \mathrm{~Pb} /{ }^{206} \mathrm{~Pb}$ weighted average ages are inferred to provide a more accurate estimate of the igneous crystallization age of all the analysed samples.

\subsubsection{Sub-volcanic rhyolite}

Sample CMR120008A (Fig. 4A; Table 1) is a grey, fine-grained, quartz- and feldspar-phyric rhyolitic rock (Fig. 3B), in which $5-10 \%$ of the rock sample is composed of quartz $>$ feldspar phenocrysts. The quartz phenocrysts are $\leqslant 1 \mathrm{~mm}$ and show embayments due to resorption. The feldspar phenocrysts are aggregates of sericitised and/or saussuritised plagioclase and K-feldspar, $1-4 \mathrm{~mm}$ in size, and have subhedral outlines. The rock is 


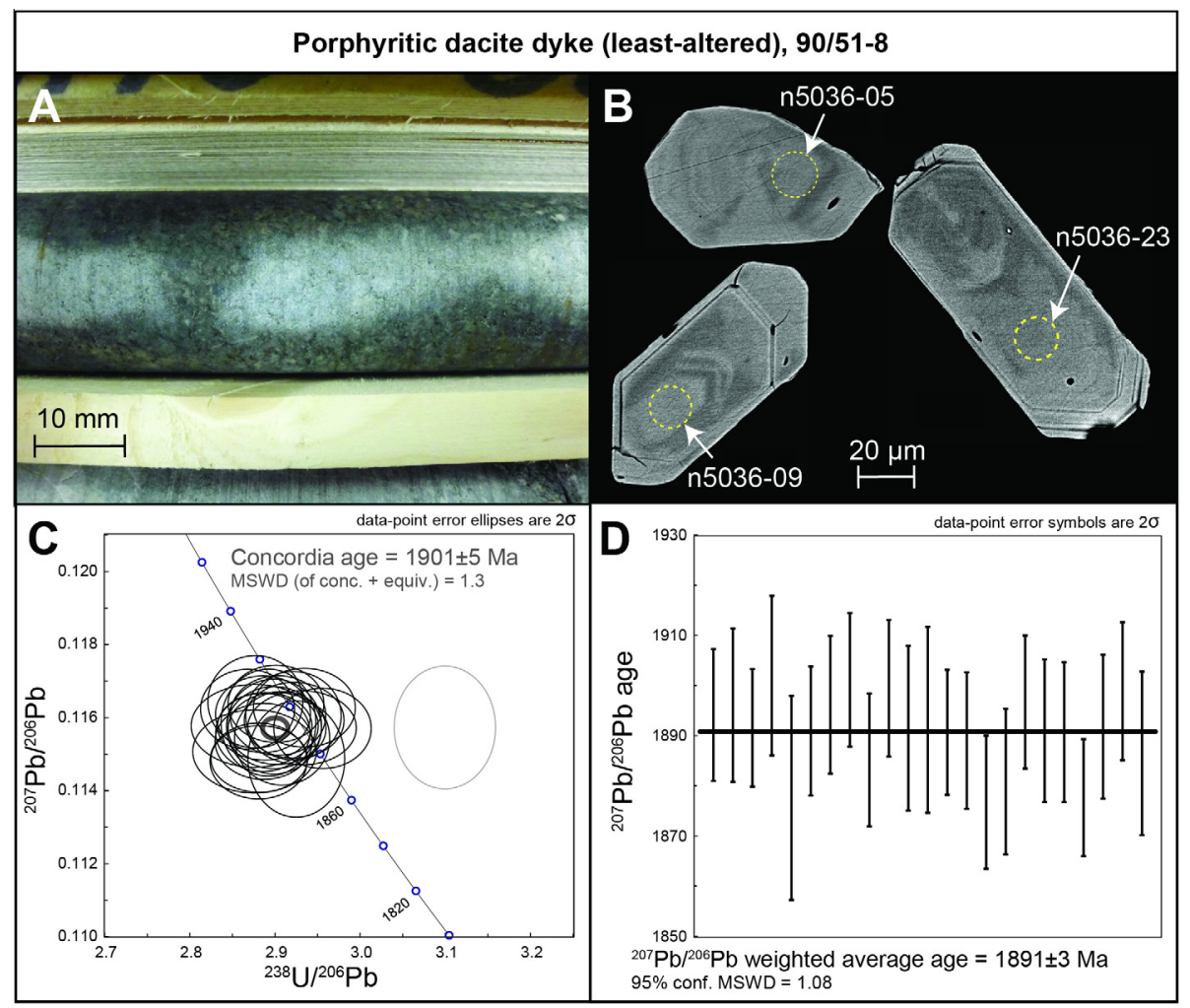

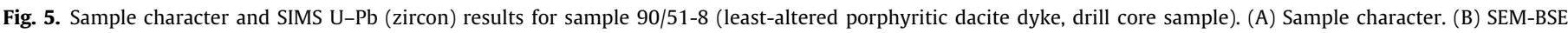

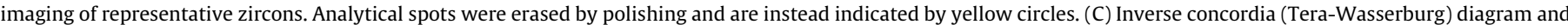

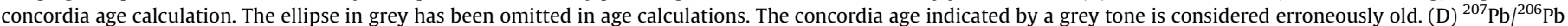

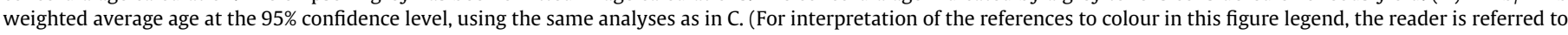
the web version of this article.)

interpreted to represent a coherent facies and a sub-volcanic mode of emplacement is inferred.

Zircon crystals extracted from this sample (Fig. 4B) are subhedral to euhedral, have lengths ranging from 80 to $100 \mu \mathrm{m}$, and show typical length/width ratios of 2-3. Under the optical microscope, the grains are mostly clear; a few show a faint brownish colouring. In some grains, minor fractures and inclusions occur, which were avoided in the analytical spot choice using BSE imaging. Characteristically, the crystal margins are sharp, although slight abrasion can be observed locally. BSE-imaging revealed oscillatory zoning in the crystals. In some crystals showing no oscillatory zoning, thicker homogeneous zones can be distinguished by a weak contrast.

In total, 15 analytical spots were selected for SIMS U-Th-Pb (zircon) analysis (Table S1). The ${ }^{207} \mathrm{~Pb} /{ }^{206} \mathrm{~Pb}$ dates of the 14 concordant spots (Fig. 4D) range from $1882 \pm 13 \mathrm{Ma}$ to $1903 \pm 8 \mathrm{Ma}$ (Table S1) and yield a weighted average of $1894 \pm 3 \mathrm{Ma}$ (MSWD $=1.7$ ) overlapping with the calculated, slightly discordant (Fig. 4C) concordia age of $1899 \pm 7 \mathrm{Ma} \quad(M S W D=1.8)$. The ${ }^{207} \mathrm{~Pb} /{ }^{206} \mathrm{~Pb}$ weighted average age is interpreted to date the timing of igneous crystallization of this sub-volcanic rock.

\subsubsection{Porphyritic dacitic dykes intruding the Falun base metal sulphide} deposit

The three samples of porphyritic dacitic dyke, 90/51-8, TKN13/22A and TKN13/61A (Figs. 5A, 6A and E, Table 1), have a fine- to medium-grained groundmass, which consists mainly of quartz, plagioclase, biotite, muscovite and K-feldspar; magnetite and minor sulphides form accessory phases. Crystals in the groundmass are statically recrystallized and some groundmass sericitisation was observed in samples TKN13/22A and
TKN13/61A. Recrystallized phenocrysts of quartz $>$ plagioclase $>$ K-feldspar (minor sericitisation) occur (Fig. 5A), which were originally medium- to coarse-grained. The subgrain boundaries show signs of meandering, which argues for a partly dynamic mode of recrystallization during ductile deformation. Muscovite and biotite form fine foliation bands, wrapping around the phenocrysts. In sample TKN13/61A, the phenocrysts were affected by more intense recrystallization and grain size decrease, but anastomosing mica foliation bands around relic phenocryst domains can be observed (Fig. 6E).

Zircon crystals have a subhedral to euhedral and elongate shape with length/width ratios of 2-4, and clear to slightly brownish colour. Minor mineral inclusions occur. SEM imaging revealed zoning with low contrasts between the domains in most of the crystals. Weak concentric zoning with $\sim 5-15 \mu \mathrm{m}$ thick domains (Fig. 5B), and fine oscillatory zoning (Fig. 6B and F) are most common. Complex zoning patterns occur in some crystals. Minor fractures are common, which typically follow the boundaries between the zircon domains.

In total, 24 (90/51-8), 12 (TKN13/22A) and 21 (TKN13/61A) spots were chosen for SIMS analysis in these samples (Table S1). Within the uncertainties obtained, the concordia $(1899 \pm 7 \mathrm{Ma}$, Fig. 6C) and ${ }^{207} \mathrm{~Pb} /{ }^{206} \mathrm{~Pb}$ weighted average (1896 $\pm 3 \mathrm{Ma}$, Fig. 6D) ages are the same for sample TKN13/22A, the latter interpreted as the igneous crystallization age of the rock. However, data regression in inverse (Tera-Wasserburg) concordia space revealed systematic reverse discordance in samples 90/51-8 (Fig. 5C) and TKN13/61A (Fig. 6G). As indicated above, the ${ }^{207} \mathrm{~Pb} /{ }^{206} \mathrm{~Pb}$ weighted average ages for these two samples (90/51-8: $1891 \pm 3$ Ma, Fig. 5D; TKN13/61A: $1896 \pm 3 \mathrm{Ma}$, Fig. $6 \mathrm{H}$ ) are considered to provide more accurate estimates of their timing of igneous crystallization. 


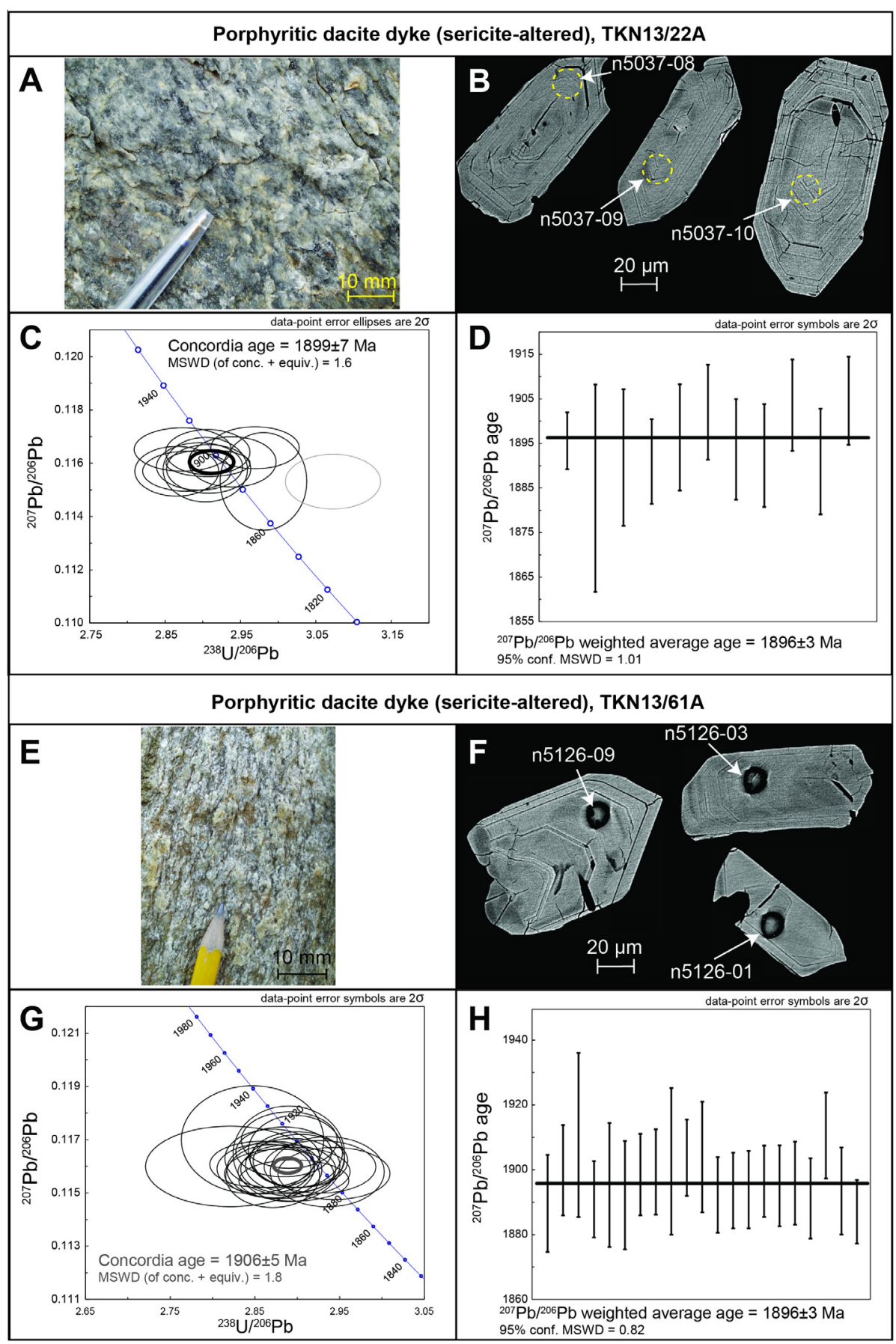

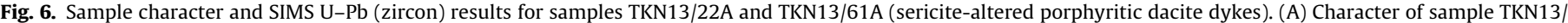

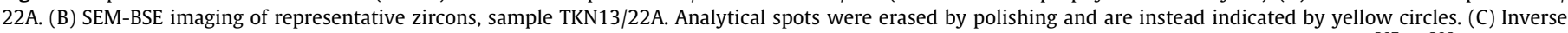

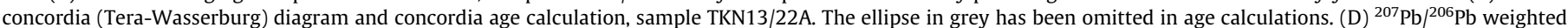

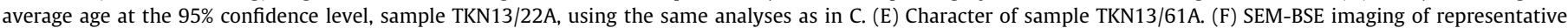

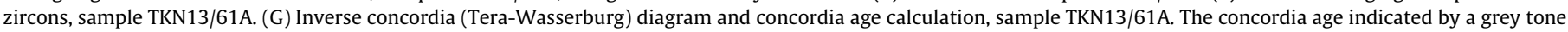

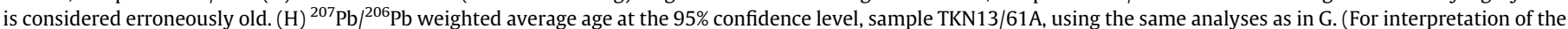
references to colour in this figure legend, the reader is referred to the web version of this article.)

\subsubsection{Granite in the GDG intrusive rock suite}

$\mathrm{U}-\mathrm{Pb}$ (zircon) dating of GDG granite (Fig. 3C; Table 1) was performed on three samples showing minor compositional and textural variation, all situated immediately to the north of the Falun inlier (Fig. 1B). Sample TKN13/43A is a metamorphosed granite (Fig. 7A) with a modal composition of $\sim 30 \%$ quartz, $\sim 20 \%$ plagioclase and $\sim 20 \% \mathrm{~K}$-feldspar, the latter being commonly sericitised. Pleochroitic green to light-brown hornblende is present (10\%) and defines a tectonic fabric. Although sample TKN13/43C has a greyer colour, it has a similar composition to sample TKN13/43A (Fig. 3C) and the boundary between the two rock varieties is gradational. Sample CMR130142A is a reddish grey, medium-grained and equigranular metamorphosed granite, taken at a field locality $\sim 10 \mathrm{~km}$ west-north-west of the Falun deposit. Locally, this granite is also hornblende-bearing. In surrounding outcrops and in local erratic boulders, the rock has enclaves that are $\mathrm{cm}$ to several $\mathrm{dm}$ 


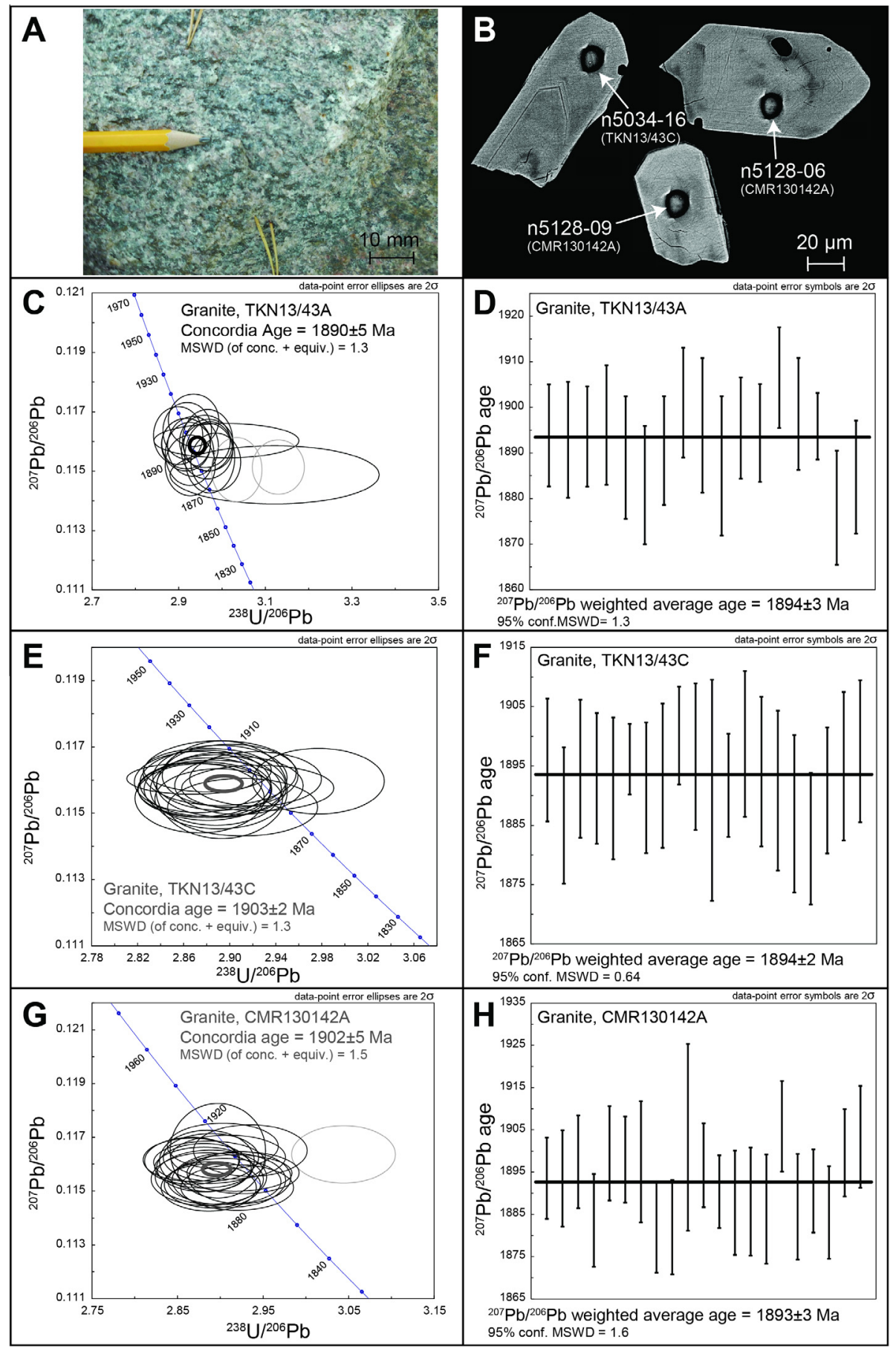

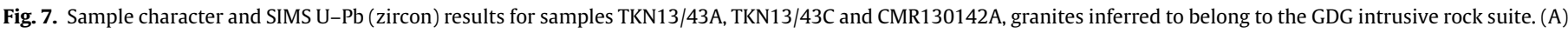

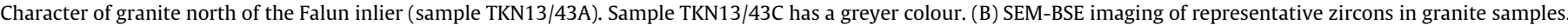

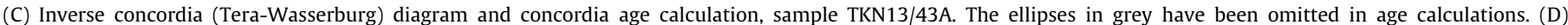

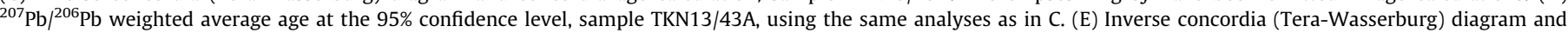

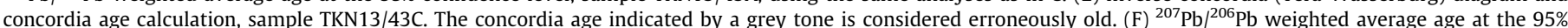

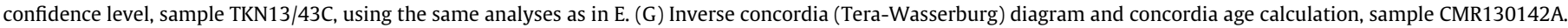

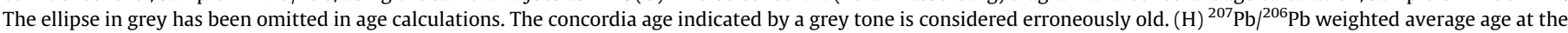
95\% confidence level, sample CMR130142A, using the same analyses as in G.

in size, have irregular and mainly rounded shapes, and consist of fine-grained, more mafic material, locally with K-feldspar phenocrysts. They are interpreted to indicate magma mingling between felsic and mafic components.

Zircons from the granite samples are similar in character to the ones extracted from the porphyritic felsic dykes. Elongate, rectangular shapes and clear to faintly brownish colours are predominant with abraded and, in some cases, altered grain boundaries.
Oscillatory and weak zoning occurs in the centre of the crystals, trending into homogeneous, unzoned domains towards the crystal margins (Fig. 7B).

In total, 19 (TKN13/43A), 20 (TKN13/43C) and 22 (CMR130142A) spots were selected for SIMS U-Th-Pb analysis (Table S1). A concordia age of $1890 \pm 5$ Ma was calculated for sample TKN13/43A, which overlaps within uncertainty with the ${ }^{207} \mathrm{~Pb} /{ }^{206} \mathrm{~Pb}$ weighted average age of $1894 \pm 3 \mathrm{Ma}$ (Fig. 7C and D). 


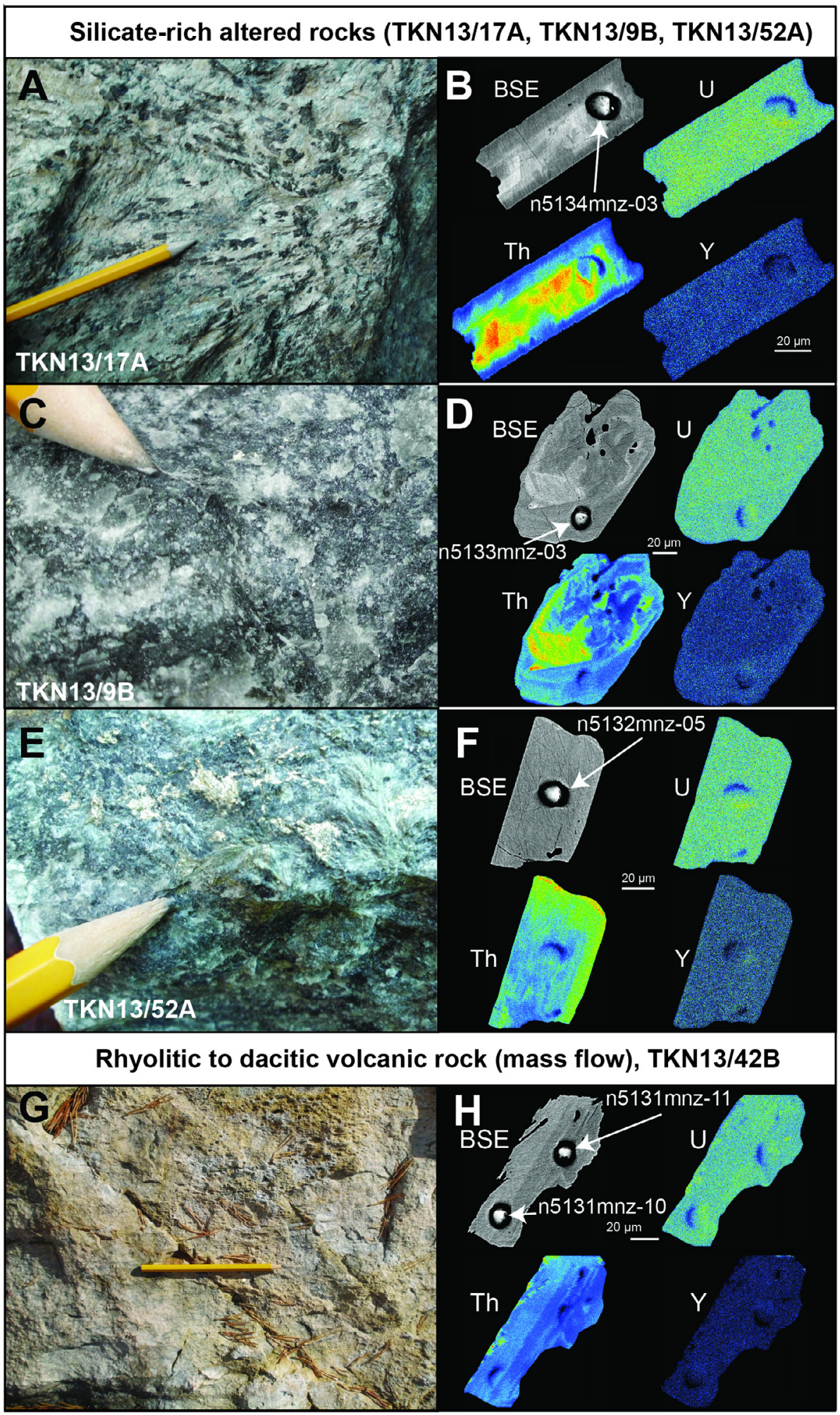

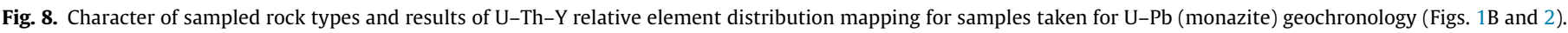

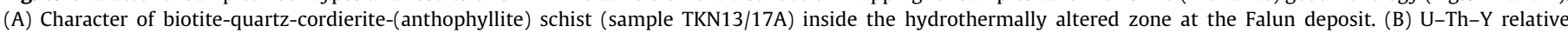

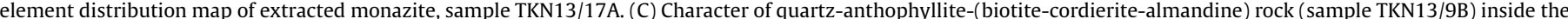

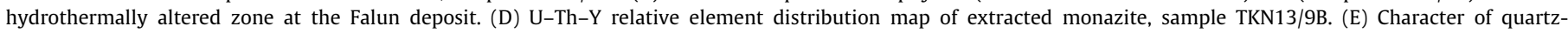

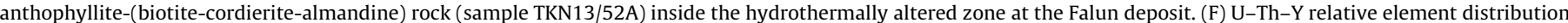

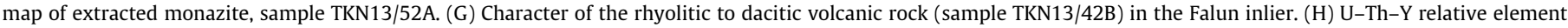
distribution map of extracted monazite, sample TKN13/42B.

Systematic reverse discordance affects data regression in inverse (Tera-Wasserburg) concordia space for samples TKN13/43C and CMR130142A (Fig. 7E and G). For this reason, the ${ }^{207} \mathrm{~Pb} /{ }^{206} \mathrm{~Pb}$ weighted average ages of $1894 \pm 2 \mathrm{Ma}$ (TKN13/43C, Fig. 7F) and $1893 \pm 3 \mathrm{Ma}$ (CMR120142A, Fig. 7H) are interpreted as more accurate estimates of the age of igneous crystallization of these 
samples, along with the ${ }^{207} \mathrm{~Pb} /{ }^{206} \mathrm{~Pb}$ weighted average age of $1894 \pm 3$ Ma for sample TKN13/43A.

\section{3. $\mathrm{U}-\mathrm{Pb}$ (monazite) geochronology}

$\mathrm{U}-\mathrm{Pb}$ (monazite) geochronology was performed on three samples of silicate-rich altered rocks from the hydrothermally altered zone at the Falun deposit (TKN13/17A, TKN13/9B and TKN13/52A; Fig. 2, Table 1) and one rhyolitic to dacitic volcanic rock (mass flow) from the Falun inlier (TKN13/42B; Fig. 1B, Table 1). The textural classification of each data point according to the observations described below, and the $\mathrm{U}-\mathrm{Th}-\mathrm{Pb}$ analytical results are shown in the Inline Supplementary Material (Table S2).

Inline Supplementary Table S2 can be found online at http:// dx.doi.org/10.1016/j.precamres.2016.03.011.

The altered rock type, from which sample TKN13/17A (Fig. 8A) has been taken, has a medium-grained, equigranular groundmass and is characterised by the mineral association biotite-quartz-cor dierite-(anthophyllite). A schistose fabric, defined by bands of oriented mineral grains and striking predominantly ENE-WSW, is developed in this lithology. Samples TKN13/9B and TKN13/52A (Fig. 8C and E, respectively) belong to an altered rock type distinctly richer in quartz and anthophyllite, with a mineral association quartz-anthophyllite-(biotite-cordierite-almandine). This rock type has a similar texture, but is structurally isotropic to only weakly foliated. Sample TKN13/42B (Fig. 8G) has a fine-grained, yellow-brown groundmass comprising mainly quartz, feldspar and minor muscovite and biotite. Medium-grained feldspar phenocrysts (10\%), as well as elongate and rounded lithic fragments (5-10\%) occur, predominantly representing fine-grained rocks with intermediate composition. Both groundmass minerals and lithic fragments are moderately deformed, defining a foliation with ENE-WSW trend.

Extracted monazites from all four samples are similar in character, both in BSE images and on U-Th-Y element distribution maps (Fig. 8). They appear colourless to slightly yellowish under the optical microscope, have rectangular prismatic to rhombohedral shapes and typical lengths of $100-200 \mu \mathrm{m}$ with length/width ratios of 2-4. Especially in the case of sample TKN13/42B, these grains represent smaller fragments of originally larger crystals (Fig. 8H). BSE-imaging reveals the presence of a homogeneous type of monazite in all samples, varying slightly in colour from mediumdark to bright grey. A second type of inhomogeneous, patchy monazite occurs in the altered rock samples TKN13/17A and TKN13/9B (Fig. $8 \mathrm{~B}$ and $\mathrm{D}$, respectively). This patchy monazite domain is typically developed in the centre of the grain, with the homogeneous domain forming the outer part. SEM-bright boundaries occur inside some grains (Fig. 8D), probably representing a former crystal boundary to the patchy monazite type.

Growth of patchy monazite is thought to involve the presence of hydrothermal fluids (e.g. Williams et al., 2007; Majka et al., 2012). Regarding samples TKN13/17A and TKN13/9B with patchy monazite, fluid flow may have occurred at some time during the geological evolution along a major talc-chlorite-(quartz-biotite) shear zone, in the vicinity of which these samples have been taken (Fig. 2). Samples TKN13/52A and TKN13/42B have been taken at some distance to any major shear zone (Figs. $1 \mathrm{~B}$ and 2), which may explain the paucity of patchy monazite in these samples.

On the U-Th-Y element distribution maps, the monazite grains from all samples show homogeneous distributions for both $U$ and $\mathrm{Y}$, relative concentrations being low to moderate for $U$ and, consistently low for Y (Fig. 8). Consistently low concentrations of $Y$ in monazite can be explained by the preferential incorporation of $Y$ in garnet in close vicinity to the sample (e.g. Williams et al. 2007). At Falun, the widespread occurrence of garnet in the silicate-rich altered rocks may explain the low relative concentrations of $\mathrm{Y}$ in monazite.

Relative Th concentrations are highly variable throughout the grains between lower to moderate and higher concentrations. BSE-bright areas, especially in the patchy domains, coincide with higher Th concentrations (Fig. 8B and D). Taking into consideration the quantitative analyses for $\mathrm{U}$ and Th during the $\mathrm{U}-\mathrm{Th}-\mathrm{Pb}$ analyses (Table S2), lower to moderate U relative concentrations correspond to a range between $523 \mathrm{ppm}$ and $1718 \mathrm{ppm} \mathrm{U}$, considering all analytical spots in Fig. 8. Regarding Th relative concentrations, the lower to moderate class corresponds to a range between 23,265 ppm and 39,906 ppm Th (n5133mnz-03, n5132mnz-05, n5131mnz-10 and n5131mnz-11; Fig. 8D, F and $\mathrm{H}$ ), whereas higher concentrations are around 73,347 ppm Th, represented by analytical spot n5134mnz-03 (Fig. 8B).

$\mathrm{U}-\mathrm{Pb}$ concordia and ${ }^{207} \mathrm{~Pb} /{ }^{206} \mathrm{~Pb}$ weighted average ages for each sample and domain have been calculated. Discordant data points (one in each of the samples TKN13/9B and TKN13/52A) and data points associated with large standard deviations (three data points each in samples TKN13/9B and TKN13/42B, and one data point in sample TKN13/52A), where $\sigma>2 \%$ for measured ${ }^{238} \mathrm{U} /{ }^{206} \mathrm{~Pb}$ and ${ }^{207} \mathrm{~Pb} /{ }^{206} \mathrm{~Pb}$ ratios, have all been excluded from the calculations. Large standard deviation can be assigned to complete penetration of the SIMS ion beam through the monazite grain and resulting lower ion flow from the sample into the mass spectrometer. Graphs and calculations of age determination are shown in the Supplementary Material (Fig. S1), and an overview of all obtained

Table 3

Summary of U-Pb (monazite) age calculation results.

\begin{tabular}{|c|c|c|c|c|}
\hline \multirow[t]{2}{*}{ Sample } & \multirow[t]{2}{*}{ Rock type } & \multirow{2}{*}{$\begin{array}{l}\text { Type of age calculation and number } \\
\text { of included data points }(n)\end{array}$} & \multicolumn{2}{|l|}{ Age of domain } \\
\hline & & & Patchy & Homogeneous \\
\hline \multirow[t]{3}{*}{ TKN13/17A } & Silicate-rich altered rock (BQC schist) & $n$ & 4 & 14 \\
\hline & & Concordia age (Ma) & $1830 \pm 12 \mathrm{Ma}$ & $1829 \pm 8 \mathrm{Ma}$ \\
\hline & & ${ }^{207} \mathrm{~Pb} /{ }^{206} \mathrm{~Pb}$ weighted average & $1830 \pm 11 \mathrm{Ma}$ & $1830 \pm 8 \mathrm{Ma}$ \\
\hline \multirow[t]{3}{*}{ TKN13/9B } & Silicate-rich altered rock (QA rock) & $n$ & 8 & 4 \\
\hline & & Concordia age (Ma) & $1823 \pm 10 \mathrm{Ma}$ & $1821 \pm 15 \mathrm{Ma}$ \\
\hline & & ${ }^{207} \mathrm{~Pb} /{ }^{206} \mathrm{~Pb}$ weighted average & $1831 \pm 10 \mathrm{Ma}$ & $1823 \pm 40 \mathrm{Ma}$ \\
\hline \multirow[t]{3}{*}{ TKN13/52A } & Silicate-rich altered rock (QA rock) & $n$ & - & 18 \\
\hline & & Concordia age (Ma) & - & $1825 \pm 7 \mathrm{Ma}$ \\
\hline & & ${ }^{207} \mathrm{~Pb} /{ }^{206} \mathrm{~Pb}$ weighted average & - & $1825 \pm 8 \mathrm{Ma}$ \\
\hline \multirow[t]{3}{*}{ TKN13/42B } & Rhyolitic to dacitic volcanic rock (mass flow) & $n$ & - & 7 \\
\hline & & Concordia age (Ma) & - & $1810 \pm 8 \mathrm{Ma}$ \\
\hline & & ${ }^{207} \mathrm{~Pb} /{ }^{206} \mathrm{~Pb}$ weighted average & - & $1808 \pm 7 \mathrm{Ma}$ \\
\hline
\end{tabular}


$\mathrm{U}-\mathrm{Pb}$ (monazite) ages is provided in Table 3. Individual $\mathrm{U}-\mathrm{Pb}$ concordia and ${ }^{207} \mathrm{~Pb} /{ }^{206} \mathrm{~Pb}$ weighted average ages for each sample overlap within analytical uncertainties (Table 3) generally within an interval between c. $1808 \mathrm{Ma}$ and $1830 \mathrm{Ma}$. For purposes of consistency with the U-Pb (zircon) geochronology work in this paper, the ${ }^{207} \mathrm{~Pb} /{ }^{206} \mathrm{~Pb}$ weighted average ages are herein used as the best estimates of the timing of crystallization of the respective monazite domains.

Inline Supplementary Figure S1 can be found online at http:// dx.doi.org/10.1016/j.precamres.2016.03.011.

Since the character of monazite from all four samples is similar (Fig. 8), U-Pb age calculations have been performed including all data points, assuming that monazite growth occurred in the same time interval in all samples (Fig. 9). All samples and data points define a tight cluster in concordia space for both patchy (Fig. 9A) and homogeneous (Fig. 9C) monazite domains (Table S2). Calculated ages for patchy monazite (U-Pb concordia: $1826 \pm 8 \mathrm{Ma}$, Fig. $9 \mathrm{~A} ;{ }^{207} \mathrm{~Pb} /{ }^{206} \mathrm{~Pb}$ weighted average: $1831 \pm 8 \mathrm{Ma}$, Fig. 9B) are slightly older, but overlap within analytical uncertainties with the ages for homogeneous monazite (U-Pb concordia: $1823 \pm 5 \mathrm{Ma}$, Fig. 9C; ${ }^{207} \mathrm{~Pb} /{ }^{206} \mathrm{~Pb}$ weighted average: $1822 \pm 5 \mathrm{Ma}$, Fig. 9D). This is consistent with the general occurrence of patchy domains in the centre of the grains. Taking the ${ }^{207} \mathrm{~Pb} /{ }^{206} \mathrm{~Pb}$ weighted average ages as a basis, monazite growth or resetting regarding the $\mathrm{U}-\mathrm{Th}-\mathrm{Pb}$ isotopic system in all samples is constrained to a short interval from $1831 \pm 8$ Ma to $1822 \pm 5$ Ma.

\section{Discussion}

5.1. Emplacement ages of magmatic suites in the vicinity of the Falun base metal sulphide deposit

The ${ }^{207} \mathrm{~Pb} /{ }^{206} \mathrm{~Pb}$ weighted average age of $1894 \pm 3 \mathrm{Ma}$ for the emplacement of the sub-volcanic rhyolite (CMR120008A) records the major phase of felsic magmatism in the Falun inlier. A similar or only slightly older age is predicted for the mega-xenoliths of felsic volcanic rock inside the sub-volcanic rocks. These results are consistent with the general age range $(1.91-1.89 \mathrm{Ga})$ for the felsic volcanism in the Bergslagen lithotectonic unit (Stephens et al., 2009). Intrusion by porphyritic dacite dykes occurred between $1896 \pm 3$ and $1891 \pm 3 \mathrm{Ma}$. These ages and their associated uncertainties overlap with the timing of felsic sub-volcanic to volcanic activity in the Falun inlier and are compatible with a comagmatic relationship between these two magmatic suites.

Emplacement of major volumes of quartz-rich plutonic rocks including granite (Fig. 1B) is constrained by three identical ${ }^{207} \mathrm{~Pb} /{ }^{206} \mathrm{~Pb}$ weighted average ages of $1894 \pm 3 \mathrm{Ma}, 1894 \pm 2 \mathrm{Ma}$ and $1893 \pm 3 \mathrm{Ma}$. The ages are consistent with the interpretation from the field relationships that these rocks belong to the 1.901.87 Ga GDG intrusive rock suite in the Bergslagen lithotectonic unit (Stephens et al., 2009). The mafic to ultramafic rocks inside the western part of and immediately surrounding the inlier are spatially associated with these quartz-rich plutonic rocks

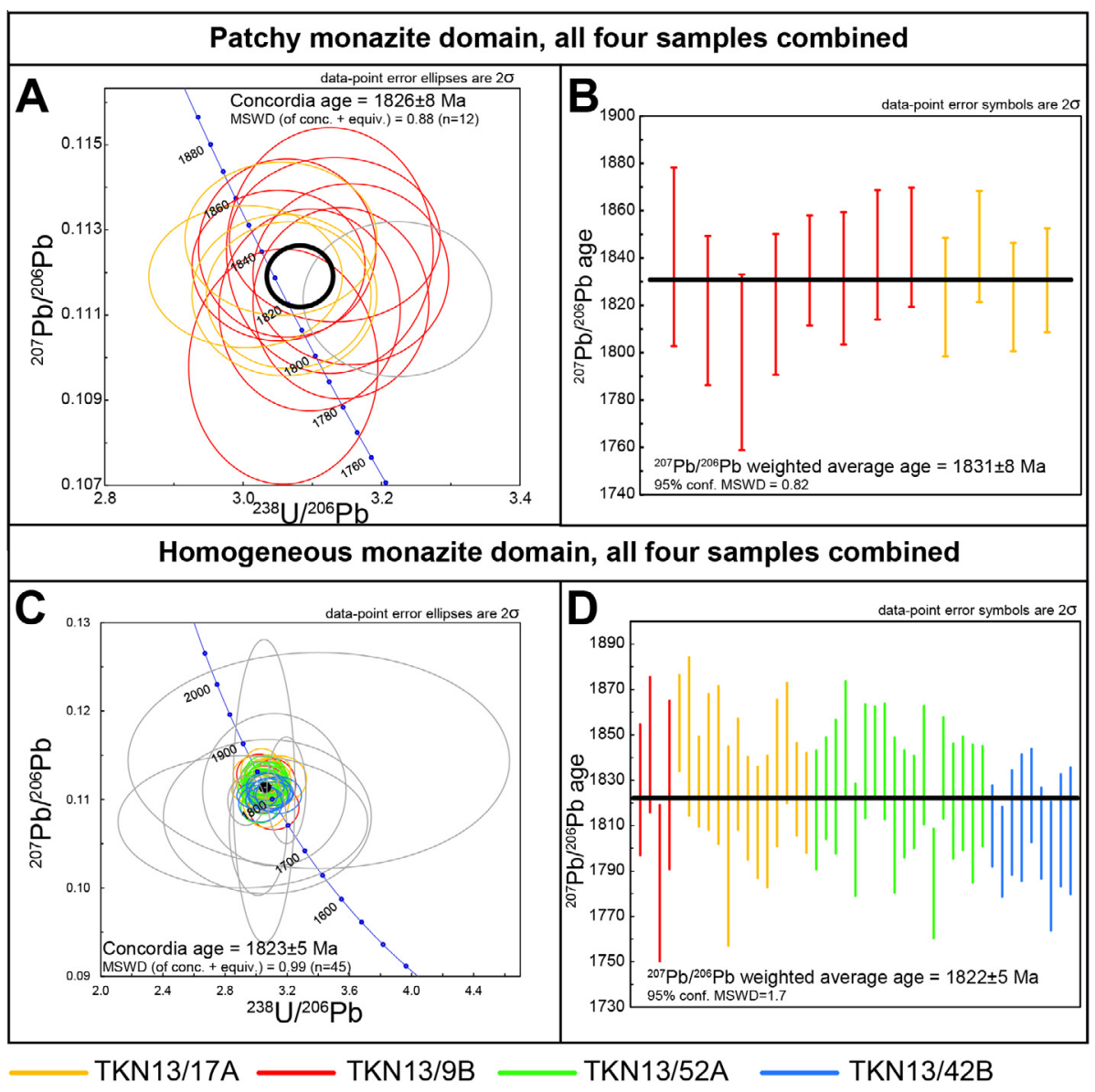

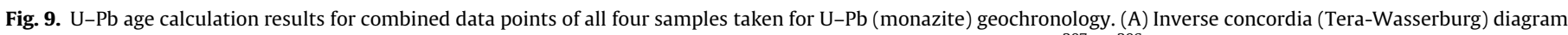

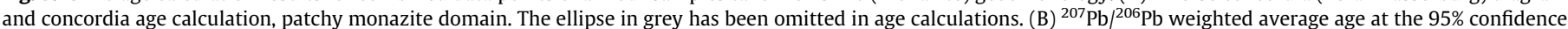

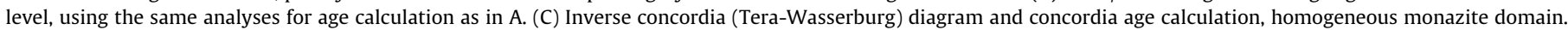

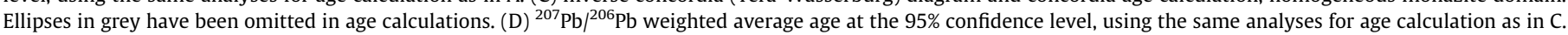


(Fig. 1B) and show a similar pattern of ductile structures. For these reasons, a similar age is inferred for these more primitive rocks. The overlapping ages between the porphyritic dacite dykes and the GDG plutonic rocks indicate a possible genetic relationship between these two magmatic suites, the dykes forming either feeders to or minor intrusions derived from the plutonic rocks.

All these ages overlap within their uncertainties and indicate a rapid geological evolution from extensive felsic volcanism and subvolcanic intrusion to emplacement of porphyritic dacite dykes and GDG plutonic rocks within a maximum interval of $11 \mathrm{Ma}$ $(1896 \pm 3 \mathrm{Ma}$ to $1891 \pm 3 \mathrm{Ma})$, taking into consideration all age uncertainties. A continuously active magmatic system during this time interval in the sub-surface realm, preceded and accompanied by continuous burial and subsidence of volcanic and carbonate rocks to a few $\mathrm{km}$ depth, is inferred. The ascent of significant magma volumes in a convergent, active continental margin setting, including mafic components (Fig. 1B), could have provided the heat input for triggering the sub-seafloor hydrothermal convection to form the pre-metamorphic hydrothermal alteration rocks and mineralisation at the Falun deposit.

\subsection{Timing of hydrothermal alteration and mineralisation at the Falun deposit}

The gradational boundary between fine-grained rhyolitic to dacitic rock and silicate-rich altered rock at the Falun base metal sulphide deposit suggests that the suite of felsic sub-volcanic to volcanic rocks around the deposit formed the precursor rock to the silicate-rich altered rock in the hydrothermally altered zone. If the age of $1894 \pm 3 \mathrm{Ma}$ for the sub-volcanic rhyolite is representative for the emplacement of this entire lithological package, this age is also a maximum age for hydrothermal alteration and sulphide mineralisation. The youngest dated dacite dyke (sample 90/51-8) cross-cuts the altered rocks and shows no mineralogical or lithogeochemical signs of hydrothermal alteration (Figs. 3 and 5A). The age determined in this study (1891 $\pm 3 \mathrm{Ma}$ ) is thus regarded as a minimum age of hydrothermal alteration and associated mineralisation. The possible causes for the sericite alteration trend observed in the other dykes dated here (samples TKN13/22A and TKN13/61A) merit further discussion.

Weak sericite enrichment is generally characteristic of hydrothermal alteration in the hanging wall or marginal footwall in, for example, VMS deposits (e.g. Large et al., 2001; Franklin et al., 2005). Assuming some such affinity component at the Falun deposit, it can be argued that the dykes affected by sericite alteration may have crystallized during the waning stages of the thermally-driven, sub-seafloor convection of fluids in connection with the hydrothermal development of the deposit, whereas the least-altered dyke (90/51-8) formed after this event. The geochronological data provide some support for this interpretation, the youngest igneous crystallization age being obtained from the least-altered dyke.

An alternative interpretation is that all dykes have been emplaced after the hydrothermal alteration and mineralisation event. In this case, sericite alteration could have occurred during the subsequent, polyphase tectonothermal evolution up to amphibolite-facies metamorphic conditions. Bearing in mind the strongly sheared contacts between the dykes and the adjacent rocks (Kampmann et al., 2016), some degree of chemical modification of the dykes during ductile shearing and metamorphism is likely. Quartz-sericite alteration associated with syn-tectonic shear zones has been observed previously, e.g. in the Mount Read Volcanics, Tasmania (Gifkins and Allen, 2001).

In summary, both the alternative interpretations for the sericite alteration discussed above are in accordance with inferred hydrothermal alteration and mineralisation at Falun having occurred between $1894 \pm 3$ Ma and $1891 \pm 3$ Ma, inside a broader time frame when intense magmatic activity in the sub-surface realm prevailed. It is clear that a more precise technique to date the timing of the different magmatic pulses is needed in order to resolve in more detail the magmatic and hydrothermal evolution at Falun.

Rhyolitic or dacitic mass flows and intrusive dacite porphyry form major components in the stratigraphic hanging wall at the Garpenberg $\mathrm{Zn}-\mathrm{Pb}-\mathrm{Ag}-(\mathrm{Cu}-\mathrm{Au})$ sulphide deposit (Allen et al., 2003), situated in a volcanic inlier $\sim 45 \mathrm{~km}$ to the south-east of the Falun deposit (Fig. 1A). In the same manner as the porphyritic dacite dykes at Falun, the hanging wall dacite porphyry at Garpenberg was emplaced during the waning stages of or after hydrothermal alteration associated with sulphide mineralisation (Allen et al., 2003). U-Pb (zircon) age determinations (Stephens et al., 2009; Jansson and Allen, 2011) of the inlier at Garpenberg bracket mineralisation to the time span of $1895 \pm 4 \mathrm{Ma}$ to $1891 \pm 2 \mathrm{Ma}$, almost identical to the age constraints for the Falun deposit presented here.

Both the Falun and Garpenberg deposits are considered to be type examples of the so-called 'Falun' (Magnusson, 1950, 1953) or stratabound volcanic-associated limestone-skarn-hosted (SVALS) deposit type (Allen et al., 1996; Jansson and Allen, 2015), which is one of two major types of polymetallic sulphide deposits in the Bergslagen ore district. However, the occurrence of large volumes of pyritic massive sulphides and disseminated $\mathrm{Cu}-\mathrm{Au}$ mineralisation in quartz-rich altered rocks at Falun, the extent of the intrusive magmatic activity around this deposit, and the more extensive evidence for mineralisation associated with the replacement of carbonate rock at Garpenberg (Allen et al., 1996, 2003; Jansson and Allen, 2015) are three components that distinguish these two deposits.

\subsection{Timing of monazite growth in a regional metamorphic context}

Even though the shapes of monazite grains from all samples as well as their chemical properties $(\mathrm{Th} / \mathrm{U}>10)$ suggest a possible magmatic origin (e.g. Bea and Montero, 1999), the internal textures (patchy and homogeneous domains) indicate a metamorphic reworking of the crystals. Apparently magmatic monazite with patchy internal textures indicating metamorphic modification has been reported previously, e.g. from the Variscan orogen of south-eastern Germany (Lisowiec et al., 2014). A magmatic age for the $\mathrm{U}-\mathrm{Pb}$ (monazite) dates in this study $(1831 \pm 8 \mathrm{Ma}$ and $1822 \pm 5 \mathrm{Ma}$; Fig. 9) can be ruled out by the U-Pb (zircon) age determination work on the magmatic rocks inside the Falun inlier. An ore-related hydrothermal nature of monazite is precluded by both the minimum age for this event at $1891 \pm 3$ Ma discussed above, and the lack of low Th/U ratios in the crystals, which would be indicative of hydrothermal monazite (e.g. Schandl and Gorton, 2004). For these reasons, the obtained ages for monazite crystallization at Falun are interpreted to date a metamorphic event during the Svecokarelian orogeny. A slightly older, patchy monazite generation is inferred to have replaced originally magmatic monazite, probably with the aid of a metamorphic fluid at $1831 \pm 8 \mathrm{Ma}$. At $1822 \pm 5 \mathrm{Ma}$, continued metamorphism, this time apparently without extensive fluid activity, led to partial replacement of the patchy domains by homogeneous monazite.

Studies on the timing of the metamorphic evolution during the Svecokarelian orogeny in the Bergslagen and Ljusdal lithotectonic units (Fig. 1A), in the south-western part of the Fennoscandian Shield, using both $\mathrm{U}-\mathrm{Pb}$ (zircon) and U-Pb (monazite) geochronology, have shown at least two episodes of high-grade metamorphism at around $1.86 \mathrm{Ga}\left(\mathrm{M}_{1}\right)$ and at $1.84-1.81 \mathrm{Ga}\left(\mathrm{M}_{2}\right)$, respectively (e.g. Andersson et al., 2006; Stephens et al., 2009; Högdahl et al., 2012; Stephens and Andersson, 2015). The U-Pb 
(monazite) ages obtained in this study (1831 $\pm 8 \mathrm{Ma}$ and $1822 \pm 5 \mathrm{Ma}$; Fig. 9) fit well within this regional metamorphic framework, coinciding with the $\mathrm{M}_{2}$ event.

Even though ${ }^{207} \mathrm{~Pb} /{ }^{206} \mathrm{~Pb}$ dates for individual data points range up to $1855 \pm 11 \mathrm{Ma}$ (Table S2), there is no statistical or textural basis for the identification of a $\mathrm{M}_{1}$-related event of monazite growth from the obtained data. However, monazite has been shown experimentally to be a relatively reactive mineral, with resetting of the $\mathrm{U}-\mathrm{Th}-\mathrm{Pb}$ isotopic system being possible even under moderate P/T conditions (Williams et al., 2011). Previously obtained metamorphic monazite ages from the Svecokarelian orogen in the south-western part of the Fennoscandian Shield, Sweden, reflect both periods of metamorphism and demonstrate, in addition, the high reactivity of monazite during metamorphism in contrast to, for example, zircon (Högdahl et al., 2012).

The resetting of the $\mathrm{U}-\mathrm{Th}-\mathrm{Pb}$ isotope systematics during $\mathrm{M}_{2}$ in the Falun inlier indicates the significant influence of this metamorphic event in the north-western part of the Bergslagen lithotectonic unit. This is in accordance with microstructural results suggesting periods of metamorphic mineral growth temporally close to the $D_{2}$ transpressive deformational event in the hydrothermally altered zone at Falun (Kampmann et al., 2016). In contrast to the results of this study, $\mathrm{U}-\mathrm{Pb}$ (zircon and titanite) and ${ }^{40} \mathrm{Ar}-{ }^{39} \mathrm{Ar}$ (hornblende) geochronology indicate the greater significance of the earlier $\mathrm{M}_{1}$ event around $1.86 \mathrm{Ga}$ in at least the north-eastern part of the Bergslagen lithotectonic unit, involving penetrative ductile deformation and peak metamorphism under amphibolite facies conditions (Hermansson et al., 2007, 2008a,b). More work is required to shed more light on the variation in the timing of peak metamorphism inside the Bergslagen lithotectonic unit.

\section{Conclusions}

Seven samples of sub-volcanic rhyolite, porphyritic dacite dykes and granite plutons taken for $\mathrm{U}-\mathrm{Pb}$ (zircon) ion probe geochronology from within and immediately surrounding the Falun inlier define a total emplacement age span from $1896 \pm 3 \mathrm{Ma}$ to $1891 \pm 3$ Ma. All individual ages in this span overlap within their uncertainties and thus indicate a close temporal relationship between these magmatic phases, consistent with previous studies in the Bergslagen lithotectonic unit (see compilation in Stephens et al., 2009). Hydrothermal alteration and mineralisation at the Falun base metal sulphide and precious metal deposit is bracketed to the interval $1894 \pm 3 \mathrm{Ma}$, for a sub-volcanic rhyolite belonging to the felsic sub-volcanic to volcanic host rock suite, and $1891 \pm 3 \mathrm{Ma}$ for a post-sulphide, dacite dyke. This age span is very similar to the timing of ore-forming processes at the Garpenberg $\mathrm{Zn}-\mathrm{Pb}-\mathrm{Ag}$ ( $\mathrm{Cu}-\mathrm{Au}$ ) sulphide deposit, situated $\sim 45 \mathrm{~km}$ south-east of Falun (1895-1890 Ma; Jansson and Allen, 2011).

A metamorphic event, herein dated at $1831 \pm 8 \mathrm{Ma}$ and $1822 \pm 5 \mathrm{Ma}$, led to the recrystallization of two respective monazite types in both volcanic host rocks around and hydrothermally altered rocks at the Falun deposit. These ages fall in the age range of a regionally observed, younger episode of metamorphism $\left(\mathrm{M}_{2}\right)$ associated with the Svecokarelian orogeny (e.g. Stephens et al., 2009), suggesting that $\mathrm{U}-\mathrm{Th}-\mathrm{Pb}$ isotope systematics in monazite has been completely reset during this event.

\section{Acknowledgements}

The Geological Survey of Sweden (SGU FoU project 61-1441/2011) and Luleå University of Technology have provided the financial support to this study. Staff at the Falun mine foundation is acknowledged for granting permission for field work and sampling in the Falun open pit. Drill core investigation and sampling was made possible by personnel at the Geological Survey of Sweden's national drill core archive in Malå, Sweden. Martin Whitehouse, Lev Ilyinsky and Kerstin Lindén (NordSIM laboratory) are thanked for their technical assistance and allocating additional time for SIMS analysis connected to this study. Reviews by Jochen Kolb, Nils Jansson and an anonymous reviewer improved the quality of the manuscript. This is NordSIM publication No. 443.

\section{References}

Åberg, A., Fallick, A.E., 1993. A fluid inclusion and light element stable isotope study of the gold-bearing quartz vein system, Falun, Sweden. Miner. Deposita 28, 324-333.

Allen, R.L., Lundström, I., Ripa, M., Simeonov, A., Christofferson, H., 1996. Facies analysis of a $1.9 \mathrm{Ga}$, continental margin, back-arc, felsic caldera province with diverse $\mathrm{Zn}-\mathrm{Pb}-\mathrm{Ag}-(\mathrm{Cu}-\mathrm{Au})$ sulphide and Fe oxide deposits, Bergslagen Region, Sweden. Econ. Geol. 91, 979-1008.

Allen, R.L., Bull, S., Ripa, M., Jonsson, R., 2003. Regional stratigraphy, Basin evolution, and the setting of stratabound $\mathrm{Zn}-\mathrm{Pb}-\mathrm{Cu}-\mathrm{Ag}-\mathrm{Au}$ deposits in Bergslagen, Project report. Geological Survey of Sweden, Uppsala, Sweden, p. 156.

Andersson, U.B., Högdahl, K., Sjöström, H., Bergman, S., 2006. Multistage growth and reworking of the Palaeoproterozoic crust in the Bergslagen area, southern Sweden: evidence from U-Pb geochronology. Geol. Mag. 143, 679-697.

Bea, F., Montero, P., 1999. Behaviour of accessory phases and redistribution of Zr, REE, Y, Th, and U during metamorphism and partial melting of metapelites in the lower crust: an example from the Kinzigite Formation of Ivera-Verbano, NW Italy. Geochim. Cosmochim. Acta 63, 1133-1153.

Beunk, F.F., Kuipers, G., 2012. The Bergslagen ore province, Sweden: review and update of an accreted orocline, 1.9-1.8 Ga BP. Precambrian Res. 216-219, 95119.

Bromley-Challenor, M.D., 1988. The Falun supracrustal belt. Part 1: primary geochemical characteristics of proterozoic metavolcanics and granites. Geol. Mijnbouw 67, 239-253.

Corfu, F., 1988. Differential response of U-Pb systems in coexisting accessory minerals. Winnipeg river subprovince, Canadian shield: implications for Archean crustal growth and stabilization. Contrib. Miner. Petrol. 98, 312-325.

Franklin, J.M., Gibson, H.L., Jonasson, I.R., Galley, A.G., 2005. Volcanogenic massive sulfide deposits. In: Economic Geology, 100th Anniversary Volume, pp. 525560.

Gavelin, S., 1989. Genesis of the Falun sulphide ores, central Sweden. GFF 111, 213227.

Geijer, P., 1917. Falutraktens berggrund och malmfyndigheter, Geological Survey of Sweden, Series C, 275, Stockholm, Sweden, 316 pp.

Gifkins, C.C. Allen, R.L., 2001. Textural and chemical characteristics of diagenetic and hydrothermal alteration in glassy volcanic rocks: examples from the mount read Volcanics, Tasmania. Econ. Geol. 96, 973-1002.

Grip, E., 1978. Sweden. In: Bowie, H.S.U., Kvalheim, A., Haslam, H.W. (Eds.), Mineral Deposits of Europe, Northwest Europe, vol. 1. Institution of Mining and Metallurgy and Mineralogical Society, London, pp. 93-198.

Hermansson, T., Stephens, M.B., Corfu, F., Andersson, J., Page, L.M., 2007. Penetrative ductile deformation and amphibolite-facies metamorphism prior to $1851 \mathrm{Ma}$ in the western part of the Svecofennian orogen, Fennoscandian Shield. Precambrian Res. 153, 29-45.

Hermansson, T., Stephens, M.B., Corfu, F., Page, L.M., Andersson, J., 2008a. Migratory tectonic switching, western Svecofennian orogen, central Sweden: constraints from U/Pb zircon and titanite geochronology. Precambrian Res. 161, 250-278.

Hermansson, T., Stephens, M.B., Page, L.M., 2008b. ${ }^{40} \mathrm{Ar} /{ }^{39} \mathrm{Ar}$ hornblende geochronology from the Forsmark area in central Sweden: constraints on late Svecofennian cooling, ductile deformation and exhumation. Precambrian Res, $167,303-315$.

Högdahl, K., Andersson, U.B., Eklund, O. (Eds.), 2004. The Transscandinavian Igneous Belt (TIB) in Sweden: A Review of Its Character and Evolution, 37. Geological Survey of Finland Special Paper, 125 p.

Högdahl, K., Majka, J., Sjöström, H., Persson Nilsson, K., Claesson, S., Konečný, P., 2012. Reactive monazite and robust zircon growth in diatexites and leucogranites from a hot, slowly cooled orogen: implications for the Palaeoproterozoic tectonic evolution of the central Fennoscandian Shield, Sweden. Contrib. Miner. Petrol. 163, 167-188.

Ishikawa, Y., Sawaguchi, T., Iwaya, S., Horiuchi, M., 1976. Delineation of prospecting targets for Kuroko deposits based on modes of volcanism of underlying dacite and alteration halos. Min. Geol. 26, 105-117.

Janoušek, V., Farrow, C.M., Erban, V., 2006. Interpretation of whole-rock geochemical data in igneous geochemistry: introducing Geochemical Data Toolkit (GCDkit). J. Petrol. 47, 1255-1259.

Jansson, N.F., Allen, R.L., 2011. Timing of volcanism, hydrothermal alteration and ore formation at Garpenberg, Bergslagen, Sweden. GFF 133, 3-18.

Jansson, N.F., Allen, R.L., 2015. Multistage ore formation at the Ryllshyttan marble and skarn-hosted $\mathrm{Zn}-\mathrm{Pb}-\mathrm{Ag}-(\mathrm{Cu})+$ magnetite deposit, Bergslagen, Sweden. Ore Geol. Rev, 69, 217-242.

Kampmann, T.C., Stephens, M.B., Weihed, P., 2016. 3D modelling and sheath folding at the Falun pyritic $\mathrm{Zn}-\mathrm{Pb}-\mathrm{Cu}-(\mathrm{Au}-\mathrm{Ag})$ sulphide deposit and implications for exploration in a $1.9 \mathrm{Ga}$ ore district, Fennoscandian Shield, Sweden. Miner. Deposita. http://dx.doi.org/10.1007/s00126-016-0638-z.

Koark, H.J., 1962. Zur Altersstellung und Entstehung der Sulfiderze vom Typus Falun. Geol. Rundsch. 52, 123-146. 
Kusiak, M.A., Whitehouse, M.J., Wilde, S.A., Nemchin, A.A., Clark, C., 2013. Mobilization of radiogenic $\mathrm{Pb}$ in zircon revealed by ion imaging: implications for early Earth geochronology. Geology 41, 291-294.

Large, R.R., Gemmell, B.J., Paulick, H., Huston, D.L., 2001. The alteration box plot: a simple approach to understanding the relationship between alteration mineralogy and lithogeochemistry associated with volcanic-hosted massive sulfide deposits. Econ. Geol. 96, 957-971.

Lisowiec, K., Budzyń, B., Słaby, E., Schulz, B., Renno, A.D., 2014. Th-U-total Pb timing constraints on the emplacement of the granitoid pluton of Stolpen, Germany. Acta Geol. Pol. 64, 457-472.

Ludwig, K.R., 2003. Isoplot 3.00: A Geochronological Toolkit for Microsoft Excel. Berkeley Geochronology Center Special Publication, pp. 1-70.

Magnusson, N.H., 1950. Zinc and lead deposits of central Sweden. In: Proceedings of the 28th International Geological Congress 1948, Great Britain, Proceedings F Part 7, pp. 371-390.

Magnusson, N.H., 1953. Malmgeologi. Jernkontoret, Stockholm, Sweden, p. 439

Majka, J., Be'eri-Shlevin, Y., Gee, D.G., Ladenberger, A., Claesson, S., Konečný, P., Klonowska, I., 2012. Multiple monazite growth in the Åreskutan migmatite: evidence for a polymetamorphic Late Ordovician to Late Silurian evolution in the Seve Nappe Complex of west-central Jämtland, Sweden. J. Geosci. 57, 3-23.

Middlemost, E.A.K., 1994. Naming materials in the magma/igneous rock system. Earth Sci. Rev. 37, 215-224.

Schandl, E.S., Gorton, M.P., 2004. A textural and geochemical guide to the identification of hydrothermal monazite; criteria for selection of samples for dating epigenetic hydrothermal ore deposits. Econ. Geol. Bull. Soc. Econ. Geol. 99, 1027-1035.

Söderlund, U., Isachsen, C.E., Bylund, G., Heaman, L.M., Patchett, P.J., Vervoort, J.D., Andersson, U.B., 2005. U-Pb baddeleyite ages and Hf, Nd isotope chemistry constraining repeated mafic magmatism in the Fennoscandian Shield from 1.6 to 0.9 Ga. Contrib. Miner. Petrol. 150, 174-194.

Stacey, J.S., Kramers, J.D., 1975. Approximation of terrestrial lead isotope evolution by a 2-stage model. Earth Planet. Sci. Lett. 26, 207-221.

Stephens, M.B., Andersson, J., 2015. Migmatization related to mafic underplating and intra- or back-arc spreading above a subduction boundary in a $2.0-1.8 \mathrm{Ga}$ accretionary orogen, Sweden. Precambrian Res. 264, 235-237.

Stephens, M.B., Weihed, P., 2013. Tectonic evolution and mineral resources in the Fennoscandian Shield, Sweden. In: Allen, R.L., Jansson, N., Ripa, M. (Eds.), Bergslagen: Geology of the Volcanic- and Limestone-hosted base Metal and Iron Oxide Deposits, Excursion Guidebook Swe 4, Proceedings of the 12th Biennial SGA Meeting 2013, Uppsala, Sweden, pp. 10-20.

Stephens, M.B., Ripa, M., Lundström, I., Persson, L., Bergman, T., Ahl, M., Wahlgren, C. H., Persson, P.O., Wickström, L., 2009. Synthesis of the bedrock geology in the
Bergslagen region, Fennoscandian Shield, south-central Sweden: Geological Survey of Sweden, Series Ba, 259, Uppsala, Sweden, 259 pp.

Tegengren, F.R., 1924. Sveriges ädlare malmer och bergverk, Geological Survey of Sweden, Series Ca, 17, Stockholm, Sweden, 406 pp.

Trägårdh, J., 1991. Metamorphism of magnesium-altered felsic volcanic rocks from Bergslagen, central Sweden. A transition from Mg-chlorite- to cordierite-rich rocks. Ore Geol. Rev. 6, 485-497.

Weijermars, R., 1987. Structure, origin, history and furture of Faluńs sulfide deposit, Bergslagen ore province, central Sweden, Report for Stora Kopparbergs Bergslags AB, 61 pp.

White, L.T., Ireland, T.R., 2012. High-uranium matrix effect in zircon and it implications for SHRIMP U-Pb age determinations. Chem. Geol. 306, 78-91.

Whitehouse, M.J., Kamber, B.S., 2005. Assigning dates to thin gneissic veins in highgrade metamorphic terranes - a cautionary tale from Akilia, southwest Greenland. J. Petrol. 46, 291-318.

Whitehouse, M.J., Kamber, B.S., Moorbath, S., 1999. Age significance of U-Th-Pb zircon data from early Archaean rocks of west Greenland - a reassessment based on combined ion-microprobe and imaging studies. Chem. Geol. 160, 201224.

Wiedenbeck, M., Allé, P., Corfu, F., Griffin, W.L., Meier, M., Oberli, F., von Quadt, A. Roddick, J.C., Spiegel, W., 1995. Three natural zircon standards for the U-Th-Pb Lu-Hf, trace element and REE analysis. Geostand. Newslett. 19, 1-23.

Wikström, A., Andersson, U.B., 2004. Geological features of the Småland-Värmland Belt along the Svecofennian margin. Part I, from the Loftahammar to the Tiveden-Askersund areas. In: Högdahl, K., Andersson, U.B., Eklund, O. (Eds.), The Transscandinavian Igneous Belt (TIB) in Sweden: A Review of its Character and Evolution, 37. Geological Survey of Finland Special Paper, pp. 22-39.

Williams, I.S., Hergt, J.M., 2000. U-Pb dating of Tasmanian dolerites: a cautionary tale of SHRIMP analysis of high-U zircon. In: Woodhead, J.D., Hergt, J.M., Noble, J.P. (Eds.), Beyond 2000: New Frontiers in Isotope Geosciences. University of Melbourne Press, Melbourne, Australia, pp. 185-188.

Williams, M.L., Jercinovic, M.J., Hetherington, C.J., 2007. Microprobe monazite geochronology: understanding geologic processes by integrating composition and chronology. Annu. Rev. Earth Planet. Sci. 2007 (35), 137-175.

Williams, M.L., Jercinovic, M.J., Harlov, D.E., Budzyń, B., Hetherington, C.J., 2011 Resetting monazite ages during fluid-related alteration. Chem. Geol. 283, 218225.

Winchester, J.A., Floyd, P.A., 1977. Geochemical discrimination of different magma series and their differentiation products using immobile elements. Chem. Geol. 20, 325-343.

Wolter, H.U., Seifert, F., 1984. Mineralogy and genesis of cordierite-anthopyllite rocks from the sulfide deposit of Falun, Sweden. Lithos 17, 147-152. 